\title{
Geochemistry of reversible hydratable tephra from the Trans Mexican Volcanic Belt
}

\author{
Liberto De Pablo, ${ }^{1, *}$ Mercedes Doval, ${ }^{2, \uparrow}$ ANd Angel La IGLesia ${ }^{3,+}$ \\ ${ }^{1}$ Instituto de Geología, Universidad Nacional Autónoma de México, 04510 México D.F., México \\ ${ }^{2}$ Departamento de Cristalografía y Mineralogía, Universidad Complutense de Madrid, 28040 Madrid, Spain \\ ${ }^{3}$ Departamento de Petrología y Geoquímica, Instituto de Geología Económica CSIC-UCM, Facultad de Ciencias Geológicas, \\ Universidad Complutense, 28040 Madrid, Spain
}

\begin{abstract}
Rhyolitic glass of high, reversible adsorption water (to $12.63 \mathrm{wt} \%$ ) occurs in pyroclastic rocks from the La Malinche stratovolcano in the Mexican Volcanic Belt. The glass constitutes 98 vol\% of the pyroclastics. It is a heterogeneous glass that dehydrates reversibly at $72{ }^{\circ} \mathrm{C}$, composed of sodic and non-sodic glasses of surface activity caused by ${ }^{\mathrm{IV}} \mathrm{Al}$ substituting in $\mathrm{Q}^{4}(1 \mathrm{Al})$ and $\mathrm{Q}^{4}(2 \mathrm{Al})$ positions, minor ${ }^{\mathrm{V}} \mathrm{Al}$, tetrahedra terminating in $\mathrm{NBOs}$, and insufficient $\mathrm{Na}$ and $\mathrm{Ca}$ to charge balance $\mathrm{Al}$ in the glass network. Adsorption is of molecular water $\mathrm{H}_{2} \mathrm{O}_{\mathrm{m}}$ in interstitial sites, $\mathrm{H}$-bonded to silanol groups, to the silica network, and to other $\mathrm{H}_{2} \mathrm{O}_{\mathrm{m}}$ molecules. Sodic glasses contain $71.80-77.77 \mathrm{wt} \%$ $\mathrm{SiO}_{2}$, are partially devitrified to crystallites $(\sim 5 \mathrm{~nm}$ size $)$ of Na-plagioclase and clinopyroxene, and exhibit minor low-grade metamorphism to $<1 \mathrm{vol} \%$ crystals of mazzite $(\sim 10 \mu \mathrm{m}$ size $)$. Sodium-free glasses are more siliceous, with 74.84-83.88 wt $\% \mathrm{SiO}_{2}$, show partial devitrification to crystallites $(\sim 5 \mathrm{~nm}$ size) of Ca-plagioclase and clinopyroxene, with minor low-grade metamorphism of glass and plagioclase to $<1$ vol $\%$ crystals of laumontite $(\sim 10 \mu \mathrm{m}$ size $)$.
\end{abstract}

Keywords: Hydratable glass, hydratable rhyolite glass, hydratable tephra, Malinche tephra, Mexican Volcanic Belt

\section{INTRODUCTION}

Pyroclastics from stratovolcanoes may contain water and volatiles that modify their properties and behavior. In the Trans Mexican Volcanic Belt, there is a chain of stratovolcanoes (Cerro Tlaloc, Iztaccihuatl, Popocatepetl, La Malinche, and Pico de Orizaba) that produced abundant andesitic to dacitic flows and pyroclastics. Among them are conspicuous rhyolitic pyroclastics of unusual adsorption properties, the knowledge of which may contribute to better understand their eruptive history and the influence of water and volatiles.

Water dissolved in magmas plays a significant role in volcanic eruptions in terms of the eruptive style, the evolution of magma properties such as viscosity, density, crystallization, mobilization of mineral components, the formation of mineral deposits, and the interaction between rocks and fluids among others. Water notably affects the physical and chemical behavior of volcanic glasses and characteristics such as chemical stability, crystal nucleation, and growth. The significance of glasses in magma characterization is increasingly important considering that glasses preserve the structural state of the melt at the bulk glass-transformation temperature (Dingwell and Webb 1990).

Volcanic glasses from lava domes and flows typically contain $0.2-0.8 \mathrm{wt} \% \mathrm{H}_{2} \mathrm{O}$. Pyroclastics may contain between
0.6-3.0 wt \% $\mathrm{H}_{2} \mathrm{O}$ (Newman et al. 1986; Zhang et al. 1991; Zhang 1999). Water contents up to $10 \mathrm{wt} \%$ have been identified in rare opal, chalcedony, and agate (Newman et al. 1986; Zotov 2003). High water contents have been attributed to absorption by pumice glass, but generally contents above $0.5 \mathrm{wt} \%$ are due to entrapped molecular water (Frondel 1982; Stolper 1982; Stolper et al. 1982; Graetsch et al. 1985; Newman et al. 1986; Ihinger et al. 1994). Contents as high as $8.0 \mathrm{wt} \% \mathrm{H}_{2} \mathrm{O}$ have been artificially incorporated into trachytic glasses at $850{ }^{\circ} \mathrm{C}$ and 20 to $200 \mathrm{mPa}$ (Di Matteo et al. 2004) and of $10 \mathrm{wt} \%$ in rhyolitic glasses at $700{ }^{\circ} \mathrm{C}$ and 5000 bar $P_{\mathrm{H}_{2} \mathrm{O}}$ (Zhang 1999).

The properties of glasses vary depending on the origin and association of water. Water may be primary water transferred from the magma or secondary water adsorbed by the glass. It may be in the form of molecular water, or as hydroxyls such as silanol ( $\mathrm{Si}-\mathrm{OH})$ and aluminol ( $\mathrm{Al}-\mathrm{OH})$, or as $\mathrm{H}^{+}$-bonded or hydronium ions $\mathrm{H}_{3} \mathrm{O}^{+}$. In the study of magmas and glasses, it is important to establish the origin of water, the mechanism of sorption, and how it affects the structural network, polymerization, stability, and reactivity of the glass (Stolper 1982; Dingwell and Webb 1990; Zhang et al. 1991; Keppler and Bagdassarov 1993; Zotov 2003).

Glasses with high contents of adsorbed water are not common. Hence, the present study focuses on a highly hydratable vitreous rhyolitic tephra from the stratovolcano La Malinche. This tephra is capable of adsorbing $12.63 \mathrm{wt} \% \mathrm{H}_{2} \mathrm{O}$. The goal of this work was to resolve the tephra geochemistry and to un- 
derstand the origin and mechanisms of its unusual high water adsorption, glass framework, the influence of water on the glass, as well as its relationships to the precursor magma.

\section{GEOLOGIC SETTING}

La Malinche is an andesitic-dacitic Quaternary stratovolcano located in the eastern trans-Mexican Volcanic Belt, Mexico (Fig. 1). The eruptive history over the last 45000 years has been predominantly explosive with the emplacement of pyroclastic flows and pumice falls. Deposits are dated at more than 39000 years, at 21500 years, and at 9000 and 7500 years. The most recent eruption 3100 years ago produced ash-fall and ash-flow deposits (CastroGovea et al. 2001). La Malinche is part of a N-S oriented volcanic chain formed by the stratovolcanoes Cerro Tlaloc, Iztaccihuatl, Popocatepetl, La Malinche, and Pico de Orizaba. La Malinche is near Popocatepetl whose recent activity indicates voluminous degassing and limited production of mixed magma consisting of two-pyroxene dacite, two-pyroxene basaltic andesite, and $\sim 3 \mathrm{wt} \%$ $\mathrm{H}_{2} \mathrm{O}$ (Witter et al. 2005). Gómez-Tuena et al. (2005) have summarized the geology of the province. The tephra described here was sampled from the flanks and east of La Malinche, in an area of study limited between $97^{\circ} 30^{\prime}-98^{\circ} 38^{\prime} \mathrm{W}$ longitude and $19^{\circ} 00^{\prime}-19^{\circ} 36^{\prime} \mathrm{N}$ latitude (Fig. 1).

\section{ANALYTICAL METHODS}

The morphology, mineralogy, and petrography of the tephra samples were determined in hand specimens, oil immersions, and thin sections. Tephra thin sections and grain mounts were prepared by impregnation with epoxy and as oil-immersed powders, respectively. Thermal behavior and water-mineral associations were analyzed simultaneously by differential thermal and thermal gravimetric analyses (DTA, TGA) using a SEIKO Extar 6000 instrument, purging with nitrogen, with a heating/cooling rate of $10 \% \mathrm{~min}$ to $1000{ }^{\circ} \mathrm{C}$. X-ray powder diffraction (XRD) analyses were obtained using a Siemens diffractometer with filtered $\mathrm{CuK \alpha}$ radiation on bulk and clay-sized fractions scanned at $1^{\circ} 2 \theta \mathrm{min}^{-1}$. Whole-rock, major, and trace element analyses were performed by X-ray fluorescence (XRF) on bulk powders fused as glass beads. Total $\mathrm{Fe}$ was analyzed by XRF and calculated as $\mathrm{FeO}$. Accuracy was monitored according to international standards and was better than $\pm 2 \%$. Loss on ignition and adsorbed water $\mathrm{H}_{2} \mathrm{O}^{+}$were determined by wet chemistry and DGA. Infrared spectra (IR) in the mid-IR region of $4000-400 \mathrm{~cm}^{-1}$ and near-IR to $5500 \mathrm{~cm}^{-1}$ were recorded, using a Varian spectrometer, from powdered material mixed with $\mathrm{KBr}$ and pressed into disks. The magic angle spinning nuclear magnetic resonance (MAS NMR) spectrum of ${ }^{27} \mathrm{Al}$ was recorded using a Varian $300 \mathrm{MHz}$ spectrometer equipped with a $7 \mathrm{~mm}$ rotor magic angle spinning (MAS) probe. Samples were spun at $6 \mathrm{KHz}$. Signals of ${ }^{27} \mathrm{Al}$ were recorded at $78 \mathrm{~Hz}$ with a $1-2 \mu \mathrm{s}$ pulse width, a spectral width of $100 \mathrm{KHz}$, and $1 \mathrm{~s}$ relaxation delay between pulses. Calibration was performed with saturated aqueous $\mathrm{AlNO}_{3} \cdot 6 \mathrm{H}_{2} \mathrm{O}$ and resonance was reported in parts per million. The morphology, microtexture, and compositions of glasses and minerals were initially determined by scanning electron microscopy (SEM) at $20 \mathrm{kV}$ operating voltage, coupled with energy dispersive X-ray (EDX) analyses on unpolished carbon-coated fragments. More complete studies were performed using SEM and lattice imaging techniques by electron diffraction on

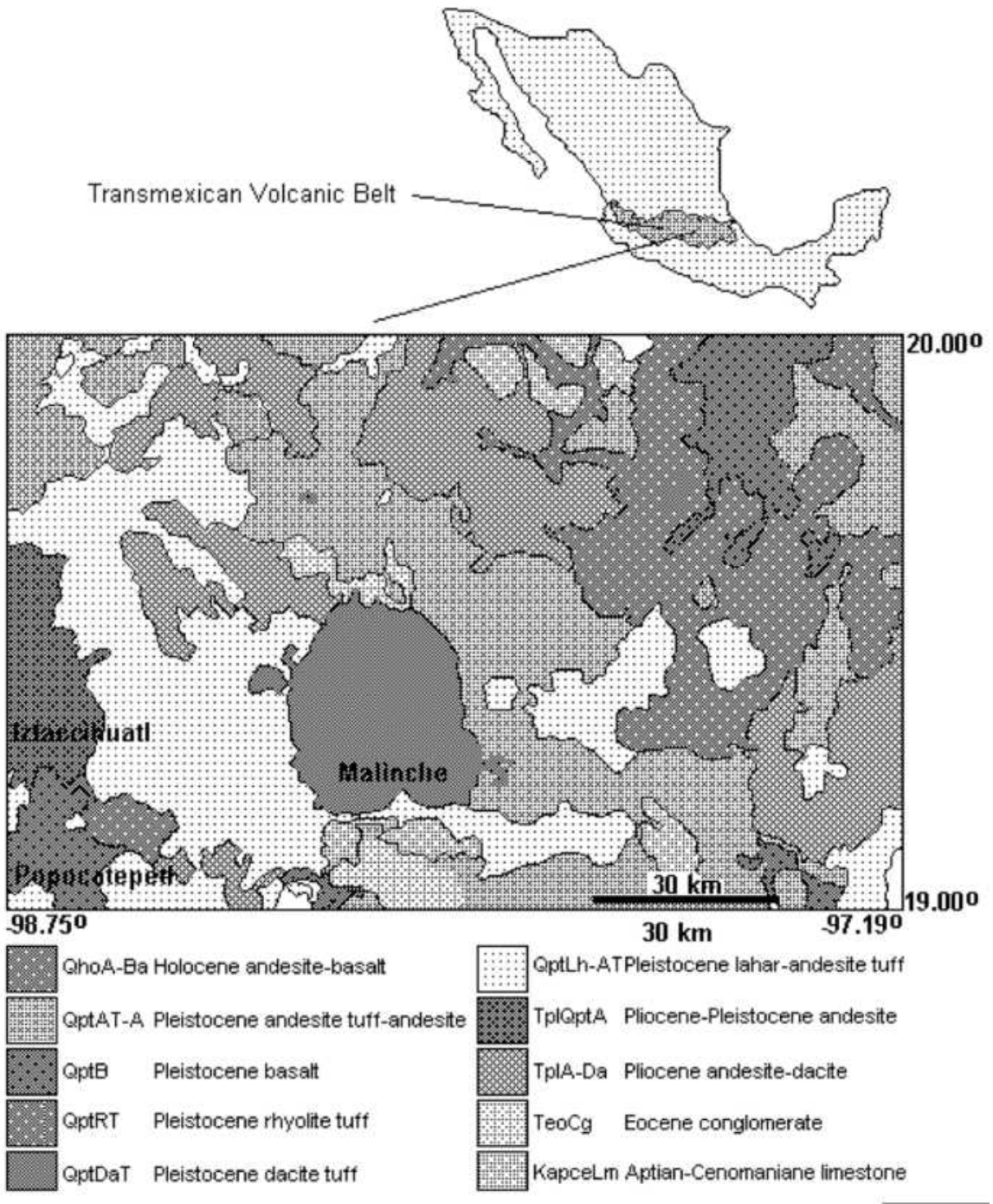

FIGURE 1. Geological sketch map of the La Malinche region in the eastern section of the Mexican Volcanic Belt. La Malinche is part of a chain of stratovolcanoes formed by Cerro Tlaloc, Iztaccihuatl, Popocatepetl, and Pico de Orizaba. Tephra was sampled from the flanks and $\mathrm{E}$ of Malinche (Servicio Geológico Mexicano 2007). 
fine material separated from ultrasonically dispersed, gently crushed bulk tephra. Analyses were done using a JEOL 2000FX scanning electron microscope operating with an acceleration voltage of $200 \mathrm{kV}$, a resolution of $3.1 \AA$, and equipped with a double inclined sample holder and an EDX Oxford ISIS spectrometer with a resolution of $136 \mathrm{eV}$ at $5.39 \mathrm{keV}$. Lattice imaging by electron diffraction was useful in selecting glass fragments free of crystallization. Transmission electron microscopy (TEM) studies at higher resolutions were performed on very fine material centrifuged from aqueous suspension after removal of coarse material, using a JEOL 3000FX metallographic electronic microscope operated at an acceleration voltage of $300 \mathrm{kV}$. Analytical data were matrix-corrected by established procedures (Electronic Microscopy Laboratory of the Universidad Complutense de Madrid) (Bence and Albee 1968; Albee and Ray 1970).

\section{RESULTS}

\section{Mineralogy and chemical composition}

La Malinche tephra is felsic in composition, comprised of whitish and colorless fragments that are slightly welded. Some exhibit a bread-crust surface, with minimal spindle-like shapes and pumice fragments. They are comprised of $\sim 95 \mathrm{vol} \%$ ash and $5 \mathrm{vol} \%$ lapilli less than $6 \mathrm{~mm}$ in size. They are $98 \%$ glass, $2 \%$ phenocrysts of augite, plagioclase, hornblende, and fragments devitrified to pyroxene. XRD results in the $2-40{ }^{\circ} 2 \theta$ range exhibit an intense halo of predominantly glass, Ca-plagioclase, augite, hypersthene, ferrosilite, calcite, and cristobalite (Fig. 2). Zeolites were not detected. Whole-rock, major, and trace element analyses correspond to a K-low rhyolitic composition (Table 1, Figs. 3, and 4) (Le Maitre 1976; Frost et al. 2001). Tephra (from optical, diffraction, and compositional data) appears as a silicoaluminate glass of $\mathrm{Si}^{4+}$ and $\mathrm{Al}^{3+}$ framework building cations, with an $\mathrm{Al}_{2} \mathrm{O}_{3} / \mathrm{SiO}_{2}$ ratio of 0.14 , and cations $\mathrm{Ti}^{4+}, \mathrm{Mg}^{2+}, \mathrm{Fe}^{2+}$, $\mathrm{Mn}^{2+}, \mathrm{Ca}^{2+}, \mathrm{K}^{+}$, and $\mathrm{Na}^{+}$totaling $12.03 \mathrm{wt} \%$ oxides and trace elements adding to $877 \mathrm{ppm}$.

The tephra loses $12.63 \mathrm{wt} \% \mathrm{H}_{2} \mathrm{O}$ on heating to $72{ }^{\circ} \mathrm{C}$ and another $0.57 \mathrm{wt} \%$ on heating to $454{ }^{\circ} \mathrm{C}$ (Fig. 5). The reactions are attributed to water and hydroxyls in the glass. Weak endothermic reactions at 645 and $952{ }^{\circ} \mathrm{C}$ are caused by structural rearrangements or by separation of water and its hydroxyl component from glass (Zhang et al. 1991; Ihinger et al. 1994). The strong dehydration at $72^{\circ} \mathrm{C}$ is reversible by standing overnight at room conditions. Heating to $500{ }^{\circ} \mathrm{C}$ removes the reactions at 72 and $454{ }^{\circ} \mathrm{C}$, but rehydration at room conditions restores the $72{ }^{\circ} \mathrm{C}$

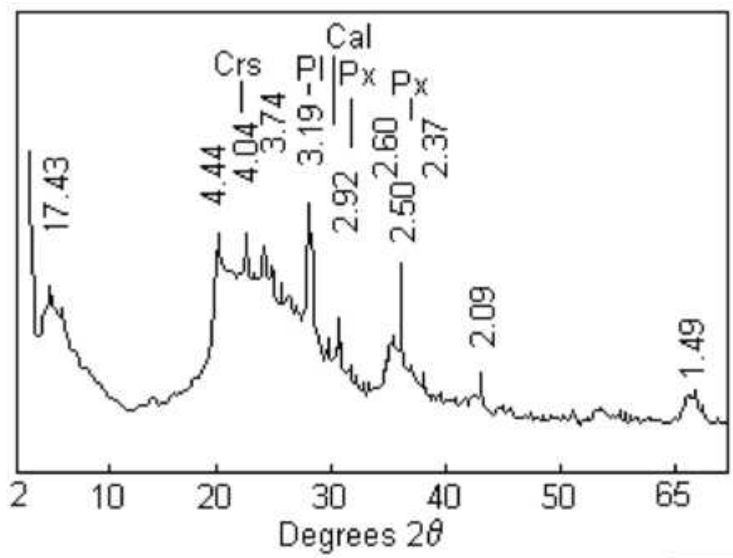

FIGURE 2. X-ray diffraction profile of rhyolitic tephra showing the halo of predominant glass overlapping weak reflections of plagioclase, pyroxene, calcite, and cristobalite.
TABLE 1. Major and trace elements composition of La Malinche tephra

\begin{tabular}{ll}
\hline $\mathrm{SiO}_{2}($ wt $\%)$ & 76.46 \\
$\mathrm{Al}_{2} \mathrm{O}_{3}$ & 10.63 \\
$\mathrm{TO}_{2}$ & 0.42 \\
$\mathrm{MgO}$ & 3.79 \\
$\mathrm{FeO}^{*}$ & 3.17 \\
$\mathrm{MnO}$ & 0.11 \\
$\mathrm{CaO}$ & 2.36 \\
$\mathrm{~K}_{2} \mathrm{O}$ & 1.28 \\
$\mathrm{Na}_{2} \mathrm{O}$ & 0.90 \\
$\mathrm{P}_{2} \mathrm{O}_{5}$ & 0.20 \\
$\mathrm{LOI}^{+}$ & 0.65 \\
$\mathrm{H}_{2} \mathrm{O}^{+}$ & 12.63 \\
& \\
$\mathrm{Rb}_{\mathrm{Spm}}$ & 74 \\
$\mathrm{Sr}$ & 192 \\
$\mathrm{Ba}$ & 181 \\
$\mathrm{Y}$ & 20 \\
$\mathrm{Zr}$ & 106 \\
$\mathrm{Nb}$ & 1 \\
$\mathrm{~V}$ & 88 \\
$\mathrm{Cr}$ & 42 \\
$\mathrm{Co}$ & 27 \\
$\mathrm{Ni}$ & 41 \\
$\mathrm{Cu}$ & 37 \\
$\mathrm{Zn}$ & 64 \\
$\mathrm{Th}$ & 4 \\
\hline
\end{tabular}

${ }^{*} \mathrm{FeO}$ is total Fe calculated as FeO. LOI loss on ignition, $\mathrm{H}_{2} \mathrm{O}^{+}$adsorbed.

reaction. The intense dehydration of $12.63 \mathrm{wt} \%$ shown by TGA does not appear to correspond with the minor amounts of crystalline minerals indicated from optical observations or by XRD.

\section{Vibration spectroscopy}

The infrared spectrum of tephra (Fig. 6; Table 2) presents a strong absorption band at $1042.47 \mathrm{~cm}^{-1}$ corresponding to the ( $\mathrm{Si}, \mathrm{Al})-\mathrm{O}$ stretching motion. Weak shoulders at 1093.46 and $1228.97 \mathrm{~cm}^{-1}$ represent asymmetric stretching of the $\mathrm{Q}^{4}(1 \mathrm{Al})$ and $\mathrm{Q}^{4}(2 \mathrm{Al})$ types. The weak shoulder at $914.30 \mathrm{~cm}^{-1}$ is identified with $\mathrm{AlOH}$ bending, octahedral $\mathrm{Al}_{2} \mathrm{OH}$, and high-pressure and -temperature $\mathrm{SiO}_{5}$ species. $\mathrm{SiOH}$ bending is indicated by the $792.61 \mathrm{~cm}^{-1}$ band. The $466.43 \mathrm{~cm}^{-1}$ band is caused by Si-O bending and M-O stretching (Iiishi et al. 1971; Rutstein and White 1971; Farmer 1974; Couty and Velde 1986; Raudsepp et al. 1987; McMillan and Hofmeister 1988; Rossman 1988; Nash and Salisbury 1990; Salisbury et al. 1991; Poe et al. 1993; Russell and Fraser 1994; Davis and Tomozawa 1996; Bishop et al. 2002a, 2002b; Johnson and Hörz 2003; Cuadros and Dudek 2006).

Water in the tephra is characterized by bending motions $v_{\mathrm{B}}\left(\mathrm{H}_{2} \mathrm{O}\right)$ at 1630.97 and $1663.54 \mathrm{~cm}^{-1}$ and their first overtones $2 v_{\mathrm{B}}\left(\mathrm{H}_{2} \mathrm{O}\right)$ at 3275.00 and $3391.37 \mathrm{~cm}^{-1}$. They are associated with molecular water $\left(\mathrm{H}_{2} \mathrm{O}_{\mathrm{m}}\right)$ Type $\mathrm{I}(\mathrm{A})$ molecules vibrating essentially free in interstitial sites and with $\mathrm{H}_{2} \mathrm{O}_{\mathrm{m}}$ Type $\mathrm{I}(\mathrm{B})$ molecules $\mathrm{H}$ bonded to silanol groups in the glass network. In the $\mathrm{OH}$ region, the strong shoulder at $3624.83 \mathrm{~cm}^{-1}$ corresponds to the $v_{\mathrm{S}}(\mathrm{OH})$ stretching motion of silanol groups and the $\mathrm{v}_{\mathrm{S}}\left(\mathrm{H}_{2} \mathrm{O}\right)_{\mathrm{III}}$ stretching of silanols $\mathrm{H}$-bonded to oxygen of neighboring $\mathrm{H}_{2} \mathrm{O}_{\mathrm{m}}$ Type III. The band could also represent hydrogen bonding between silanols and the silica network of the type $\equiv \mathrm{SiOH} \cdots \mathrm{O}=$ displaced from the known $3672 \mathrm{~cm}^{-1}$ frequency by intense hydration and H-bonding (Davis and Tomozawa 1996).

The $3472.94 \mathrm{~cm}^{-1}$ band assigned to $\mathrm{V}_{\mathrm{S}}\left(\mathrm{H}_{2} \mathrm{O}\right)_{\text {I and II }}$ is a combination band that includes asymmetric stretching $\mathrm{v}_{\mathrm{AS}}\left(\mathrm{H}_{2} \mathrm{O}\right)_{\mathrm{II}}$ from molecular water $\mathrm{H}_{2} \mathrm{O}_{\mathrm{m}}$ Type II molecules bound to the silica 


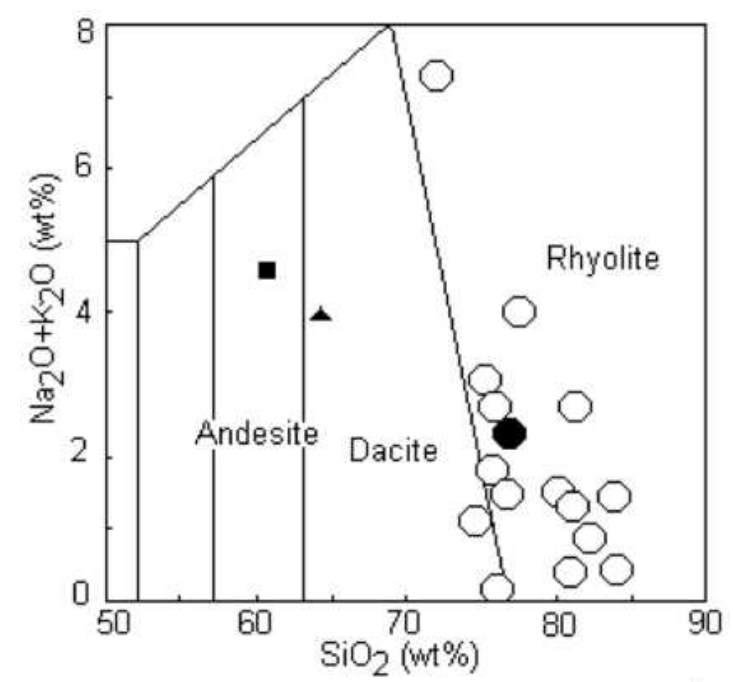

FIGURE 3. Tephra and glass compositions plotted on a TAS diagram. Andesitic and dacitic tephras from the same area are included (Source: Le Maitre et al. 1976; Le Bas et al. 1986). Symbols: circle = rhyolitic, square $=$ andesitic, triangle $=$ dacitic. Open symbols are glass; filled symbols are tephra.

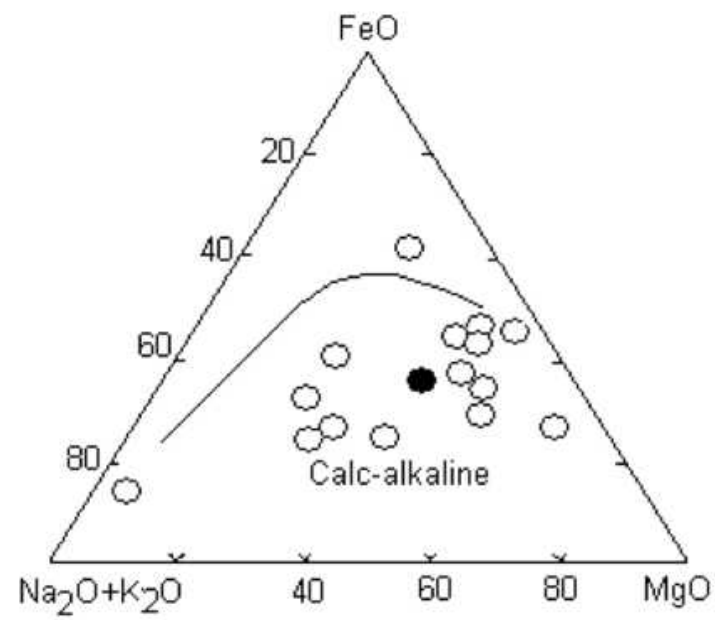

FIGURE 4. Compositions of tephra and glasses plotted on an AFM diagram. The line marks the boundary between tholeiitic and calc-alkaline fields. Symbols: open circle $=$ rhyolitic, filled circle $=$ tephra $($ Irving and Baragar 1971).

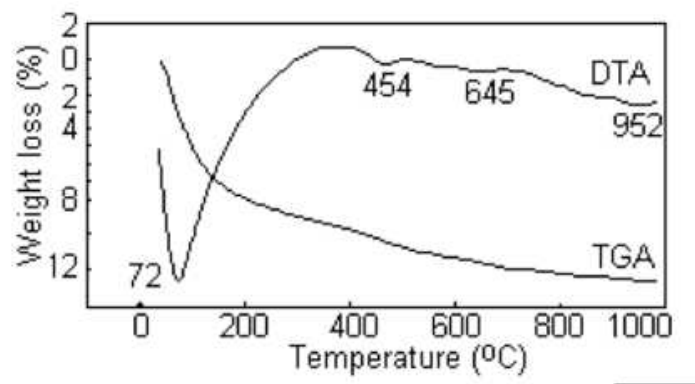

FIGURE 5. Differential and thermal gravimetric analyses profiles of tephra. Tephra loses $12.63 \mathrm{wt} \% \mathrm{H}_{2} \mathrm{O}$ at $72{ }^{\circ} \mathrm{C}$ and $0.57 \mathrm{wt} \%$ at $454{ }^{\circ} \mathrm{C}$; weak endothermic reactions at 645 and $952^{\circ} \mathrm{C}$ are attributed to structural rearrangements in the glass. network and symmetric stretching $v_{\mathrm{SS}}\left(\mathrm{H}_{2} \mathrm{O}\right)_{\mathrm{I}}$ from free $\mathrm{H}_{2} \mathrm{O}_{\mathrm{m}} /$ hydrogen bonded $\mathrm{H}_{2} \mathrm{O}_{\mathrm{m}}$ Type I(A) molecules inside the glass. These are expected at 3450 and $3425 \mathrm{~cm}^{-1}$ in silica glasses (Davis and Tomozawa 1996). In La Malinche tephra, the 3472.94 frequency suggests a dominant contribution from Type II molecules. The absorbance of the $3472.94 \mathrm{~cm}^{-1}$ band caused by $\mathrm{H}_{2} \mathrm{O}_{\mathrm{m}}$ motions is higher than the absorbance of the $3624.83 \mathrm{~cm}^{-1}$ shoulder from $\mathrm{OH}$ motions hence pointing to low-temperature hydration of the glass (Davis and Tomozawa 1996). Hydration at high temperatures and partial water pressures would have incorporated less $\mathrm{H}_{2} \mathrm{O}_{\mathrm{m}}$ and more $\mathrm{OHs}$ (hydroxyls) in the glass. The low-absorbance band at $5230.22 \mathrm{~cm}^{-1}$ bending (Fig. 7) is a combination band that adds contributions from stretching motions $\mathrm{v}_{\mathrm{B}}\left(\mathrm{H}_{2} \mathrm{O}\right)+\mathrm{v}_{\mathrm{s}}\left(\mathrm{H}_{2} \mathrm{O}\right)$ of $\mathrm{H}_{2} \mathrm{O}_{\mathrm{m}}$. It sustains the predominance in tephra of molecular water $\mathrm{H}_{2} \mathrm{O}_{\mathrm{m}}$ over hydroxyls $\mathrm{OH}$.

Additionally, the lack of some characteristics in IR spectra support the predominance of low-temperature hydration. They are the $\sim 944 \mathrm{~cm}^{-1}$ stretching mode $\mathrm{v}_{\mathrm{As}}\left(\mathrm{O}_{1} \mathrm{SiOH}{ }^{\cdots \mathrm{H}} \mathrm{O}\right)$ of $\mathrm{SiO}$ in silanols $\mathrm{H}$-bonded to $\mathrm{O}$ atoms of neighboring silanol groups at low $\mathrm{H}_{2} \mathrm{O}_{\mathrm{m}}$ contents or to oxygen of $\mathrm{H}_{2} \mathrm{O}$ molecules at high $\mathrm{H}_{2} \mathrm{O}_{\mathrm{m}}$ contents (Davis and Tomozawa 1996), the $3510 \mathrm{~cm}^{-1} \mathrm{OH}$ stretching $\mathrm{v}_{\mathrm{S}}\left(\mathrm{OH}{ }^{\cdots{ }^{\mathrm{H}} \mathrm{OSi}}\right)$ of silanols $\mathrm{H}$-bonded to the oxygen of neighboring silanols, and the $\sim 4566 \mathrm{~cm}^{-1}$ band from silanol groups hydrogen bonded to $\mathrm{H}_{2} \mathrm{O}$ molecules. Also absent are the $964 \mathrm{~cm}^{-1} \mathrm{SiO}$ asymmetric stretching of $\mathrm{v}_{\mathrm{AS}}\left(\mathrm{O}_{3} \mathrm{SiOH}\right)$ and $v_{\mathrm{AS}}\left(\mathrm{O}_{1} \mathrm{SiO}\right)$ and the $2820-2810 \mathrm{~cm}^{-1}$ stretching $\mathrm{v}_{\mathrm{S}}(\mathrm{OH} \cdots \mathrm{X})$ corresponding to $\mathrm{OH}$ stretching of silanols H-bonded to nonbridging $\mathrm{O}$ atoms (NBOs).

\section{${ }^{27}$ Al MAS NMR}

The predominant form of ${ }^{27} \mathrm{Al}$ in tephra is tetrahedral coordinated ${ }^{\mathrm{IV}} \mathrm{Al}$ characterized by the intense broad shift at $56.241 \mathrm{ppm}$ and slightly skewed toward more shielded positions (Fig. 8). Octahedral ${ }^{\mathrm{VI}} \mathrm{Al}$ is defined by the weak broad shift at $-0.937 \mathrm{ppm}$, whereas low-intensity shoulders at $38.8,33.3$, and $28.3 \mathrm{ppm}$ indicate minor association of ${ }^{\mathrm{V}} \mathrm{Al}$. The 3.7 intensity ratio between shifts of ${ }^{\mathrm{IV}} \mathrm{Al}$ and ${ }^{\mathrm{VI}} \mathrm{Al}$ establishes the dominance of tetrahedral ${ }^{\mathrm{IV}} \mathrm{Al}$.

The $56.241 \mathrm{ppm}$ motion is within the known range of 50-80 ppm for silicoaluminate, $\mathrm{CaMgSi}_{2} \mathrm{O}_{6}-\mathrm{CaAl}_{2} \mathrm{SiO}_{6}$ (diopside-Ca-Tschermak), anorthite, $\mathrm{CaAl}_{2} \mathrm{O}_{4}$, Italian and

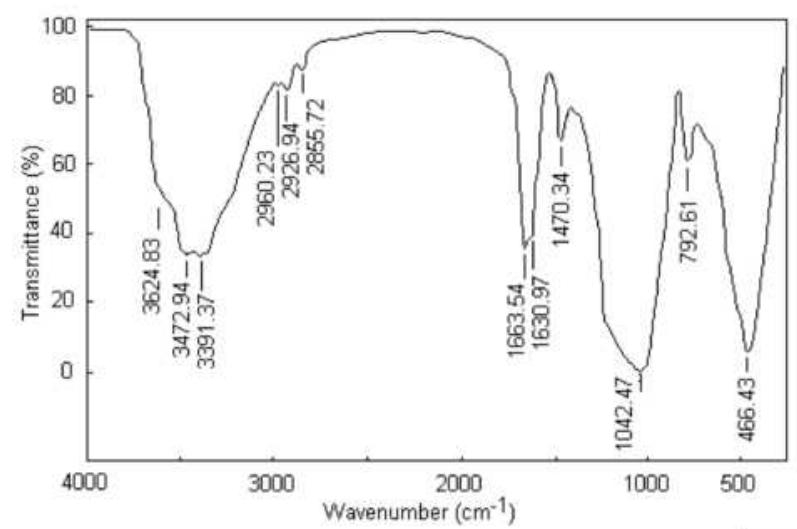

FIGURE 6. Mid-infrared absorption spectra of tephra showing $\mathrm{H}_{2} \mathrm{O}$ and $\mathrm{OH}$ stretching, $\mathrm{H}^{+}$-bonded $\mathrm{H}_{2} \mathrm{O}, \mathrm{H}_{2} \mathrm{O}$ bending, and $\mathrm{Si}$, Al stretching. See text for discussion. 
TABLE 2. Infrared absorption bands from La Malinche tephra

\begin{tabular}{|c|c|c|c|}
\hline Wavenumber & Intensity & Characteristic & Assignment \\
\hline 466.43 & $\mathrm{~s}$ & SiO bending, $\mathrm{MO}$ stretching & $v_{B}(\mathrm{SiO})$ \\
\hline 520.00 & wsh & $\mathrm{H}_{2} \mathrm{O}$ hindered rotation & $v_{\mathrm{R}}\left(\mathrm{H}_{2} \mathrm{O}\right)$ \\
\hline 792.61 & $\mathrm{~m}$ & SiAIOH bending & $\mathrm{v}_{\mathrm{B}}(\mathrm{SiAIOH})$ \\
\hline 914.30 & wsh & $\mathrm{AlOH}$ bending & $\mathrm{v}_{\mathrm{B}}(\mathrm{AlOH})$ \\
\hline 1042.47 & $\mathrm{~s}$ & SiAIO stretching & $v_{s}(\mathrm{SiAlO})$ \\
\hline 1093.46 & ssh & SiAlO stretching & $v_{s}(\mathrm{SiAlO})$ \\
\hline 1228.97 & wsh & SiAlO stretching & $v_{s}(\mathrm{SiAlO})$ \\
\hline 1630.97 & s & $\mathrm{H}_{2} \mathrm{O}$ bending & $v_{B}\left(H_{2} \mathrm{O}\right)$ \\
\hline 1663.54 & $\mathrm{~s}$ & $\mathrm{H}_{2} \mathrm{O}$ bending & $v_{B}\left(H_{2} \mathrm{O}\right)$ \\
\hline 3275.00 & wsh & first overtone of $\mathrm{H}_{2} \mathrm{O}$ bending & $2 \mathrm{v}_{\mathrm{B}}\left(\mathrm{H}_{2} \mathrm{O}\right)$ \\
\hline 3391.37 & $\mathrm{~s}$ & first overtone of $\mathrm{H}_{2} \mathrm{O}$ bending & $2 \mathrm{v}_{\mathrm{B}}\left(\mathrm{H}_{2} \mathrm{O}\right)$ \\
\hline 3472.94 & $\mathrm{~s}$ & $\mathrm{H}_{2} \mathrm{O}$ stretching & $\mathrm{V}_{\mathrm{S}}\left(\mathrm{H}_{2} \mathrm{O}\right)_{\text {land }}$ \\
\hline 3624.83 & ssh & OH stretching & $\mathrm{v}_{\mathrm{s}}(\mathrm{OH})$ \\
\hline 5230.22 & w & $\mathrm{H}_{2} \mathrm{O}$ bending + stretching & $\mathrm{V}_{\mathrm{B}}\left(\mathrm{H}_{2} \mathrm{O}\right)+\mathrm{V}_{5}\left(\mathrm{H}_{2} \mathrm{O}\right)$ \\
\hline
\end{tabular}

Notes: Wavenumber in $\mathrm{cm}^{-1}$. Intensity: $\mathrm{s}=$ strong; $\mathrm{w}=$ weak; $\mathrm{sh}=$ shoulder.

Japanese glasses (Müller et al. 1981a, 1981b; Kirkpatrick et al. 1985, 1986; Oestrike et al. 1987; Kirkpatrick 1988; Stebbins 1995; Baltisberger et al. 1996; Petrini et al. 1999; Slejko et al. 2003; Neuville et al. 2004, 2007; Hiradate and Wada 2005; Massiot et al. 2008) and for framework and layer silicates (Fyfe et al. 1982; Hovis et al. 1992; Kinsey et al. 1985; Lippman et al. 1986; Oestrike et al. 1987; Phillips et al. 1992; Wang et al. 2002a). Triclusters of $\mathrm{AlO}_{4}\left(\mathrm{~T}^{*}\right), \mathrm{AlO}_{4}(\mathrm{~T} 9)$ with vacant sites, and $\mathrm{Si} / \mathrm{Al}$ substitutions have shifts at 55.0 and at $45.7 \mathrm{ppm}$ (Hovis et al. 1992; Rehak et al. 1998).

The ${ }^{\mathrm{VI}} \mathrm{Al}$ shift at $-0.937 \mathrm{ppm}$ occurs within the 15 to -10 ppm known range for silicoaluminate glasses (Kirkpatrick 1988; Stebbins 1995; Petrini et al. 1999; Stebbins et al. 2000; Slejko et al. 2003; Allwardt et al. 2005a, 2005b, 2007) and silicates (Dirken et al. 1992; Rehak et al. 1998; Kelsey et al. 2008). The ${ }^{\mathrm{V}} \mathrm{Al}$ shifts at $38.8,33.3$, and $28.3 \mathrm{ppm}$ are within the known range of 25-35 ppm (Kirkpatrick 1988; Stebbins 1995; Wang et al. 2002b; Allwardt et al. 2007), of 34.9-44.2 ppm for polyhedral $\mathrm{AlO}_{5}$ in $\mathrm{SiO}_{2}-\mathrm{Al}_{2} \mathrm{O}_{3}-\mathrm{CaO}$ glasses (Neuville et al. 2004), and of 38.7-33.6 ppm for $\mathrm{Al}_{2} \mathrm{O}_{3}-\mathrm{CaO}$ glasses (Neuville et al. 2007). The intense motion at $108.732 \mathrm{ppm}$ (Fig. 8) corresponds to a static peak or to a satellite transition caused by a first-order quadrupolar interaction exceeding the sample rotation frequency.

\section{Electron microscopy}

Less than $2 \%$ of the tephra is comprised of well-developed crystals $(\sim 10 \mu \mathrm{m}$ in size $)$ of pigeonite oriented along their $z$ axis in a flow pattern (Figs. 9b and 9d; compositions 2 and 3 in Table 3), tabular augite (Fig. 9c; composition 1 in Table 3), and prismatic ferrosilite (Figs. 9e, 9f, and 9g; compositions 4, 5, and 6 in Table 3). Laumontite occurs as a few thin tabular oriented crystals in glass (Figs. 9h and 9i; compositions 7 and 8 in Table 3 ) and as an authigenic replacement of plagioclase (Fig. 9e; composition 9 in Table 3) associated with authigenic calcite (Fig. 9j). Mazzite appears as thin hexagonal prisms in glass (Figs. 9a and 9f; compositions 10 and 12 in Table 3).

Scanning electron microscope studies, using a $200 \mathrm{kV}$ operating voltage, show a variety of textural features: (a) plagioclase phenocrysts $(150-400 \mathrm{~nm})$ partially dissolved in glass devitrified to microlithic plagioclase crystallites of $<5 \mathrm{~nm}$ (Fig. 10a; glass composition M4 in Table 4), (b) augite phenocrysts fragmented to smaller prismatic crystals (Fig. 10b), (c) augite phenocrysts in glass devitrified to minute pyroxene crystallites oriented along a flow pattern (Fig. 10c; glass composition M12 in Table 4),

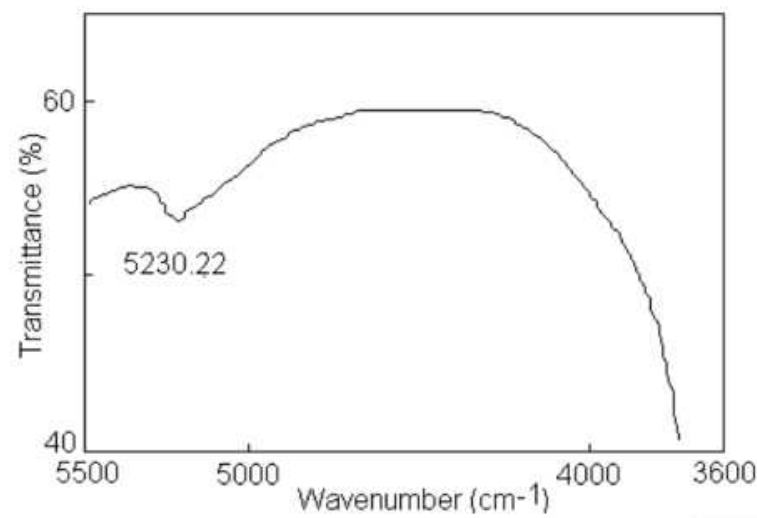

FIGURE 7. Near-infrared absorption spectra of tephra indicating the $5230.22 \mathrm{~cm}^{-1}$ low-absorbance combination band of bending and stretching motions from molecular water. The $\sim 4566 \mathrm{~cm}^{-1}$ band from silanol groups $\mathrm{H}^{+}$-bonded to $\mathrm{H}_{2} \mathrm{O}$ molecules is absent.

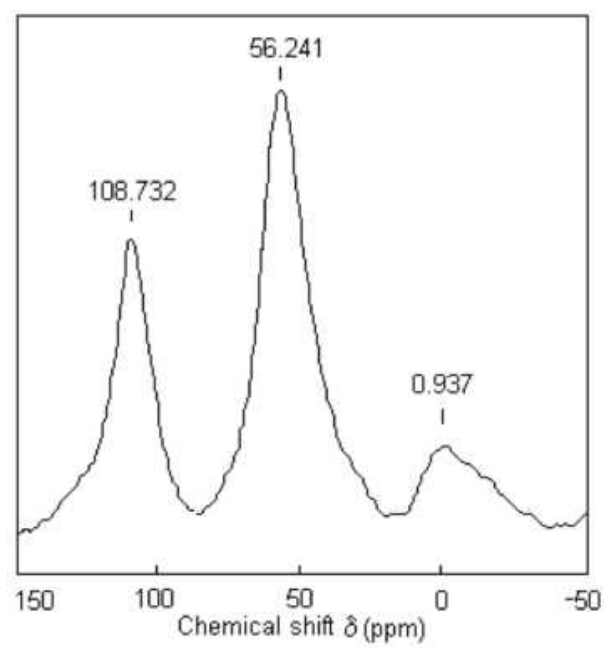

FIGURE 8. Nuclear magnetic resonance NMR MAS spectrum of ${ }^{27} \mathrm{Al}$ from tephra. Shifts arise from ${ }^{\mathrm{VI}} \mathrm{Al}$ at $-0.937 \mathrm{ppm}$, minor ${ }^{\mathrm{V}} \mathrm{Al}$ at 38.8 and $33.3 \mathrm{ppm}$, and ${ }^{\mathrm{IV}} \mathrm{Al}$ at $56.241 \mathrm{ppm}$. Motion at $108.732 \mathrm{ppm}$ may correspond to a static peak or to a satellite transition.

(d) cryptocrystalline aggregates of prismatic and feathery pyroxenes (Fig. 10d; composition M14 in Table 4), (e) glass shard fragmented and devitrified to tabular and prismatic pyroxene (Fig. 10e; composition M9 Table 4), and (f) shard devitrified to tabular pyroxene covered by feathery pyroxene (Fig. 10f).

Transmission electron microscope studies, using a $300 \mathrm{kV}$ operating voltage, show drops of viscous glass (10 to $60 \mathrm{~nm}$ size) enclosing pyroxene crystals ( $\sim 5 \mathrm{~nm}$ size) (Figs. 11a, 11c, and 11d) containing $\mathrm{Si}, \mathrm{Fe}, \mathrm{Ca}, \mathrm{Mg}$, and $\mathrm{Al}$ (Fig. 11b). Some analyses include $\mathrm{Na}$ and/or $\mathrm{K}$. A pyroxene phenocryst exhibits lamination (Fig. 11e) and metasomatism through intercalation of amphibole chains between pyroxene chains with the measured $c$ dimension of the crystals being $5.23 \AA$ transverse to the long direction of the crystals (Fig. 11f).

\section{Glass and mineral compositions}

The compositions of glasses from fragments or parts of fragments that do not exhibit crystallinity by electron diffraction are 

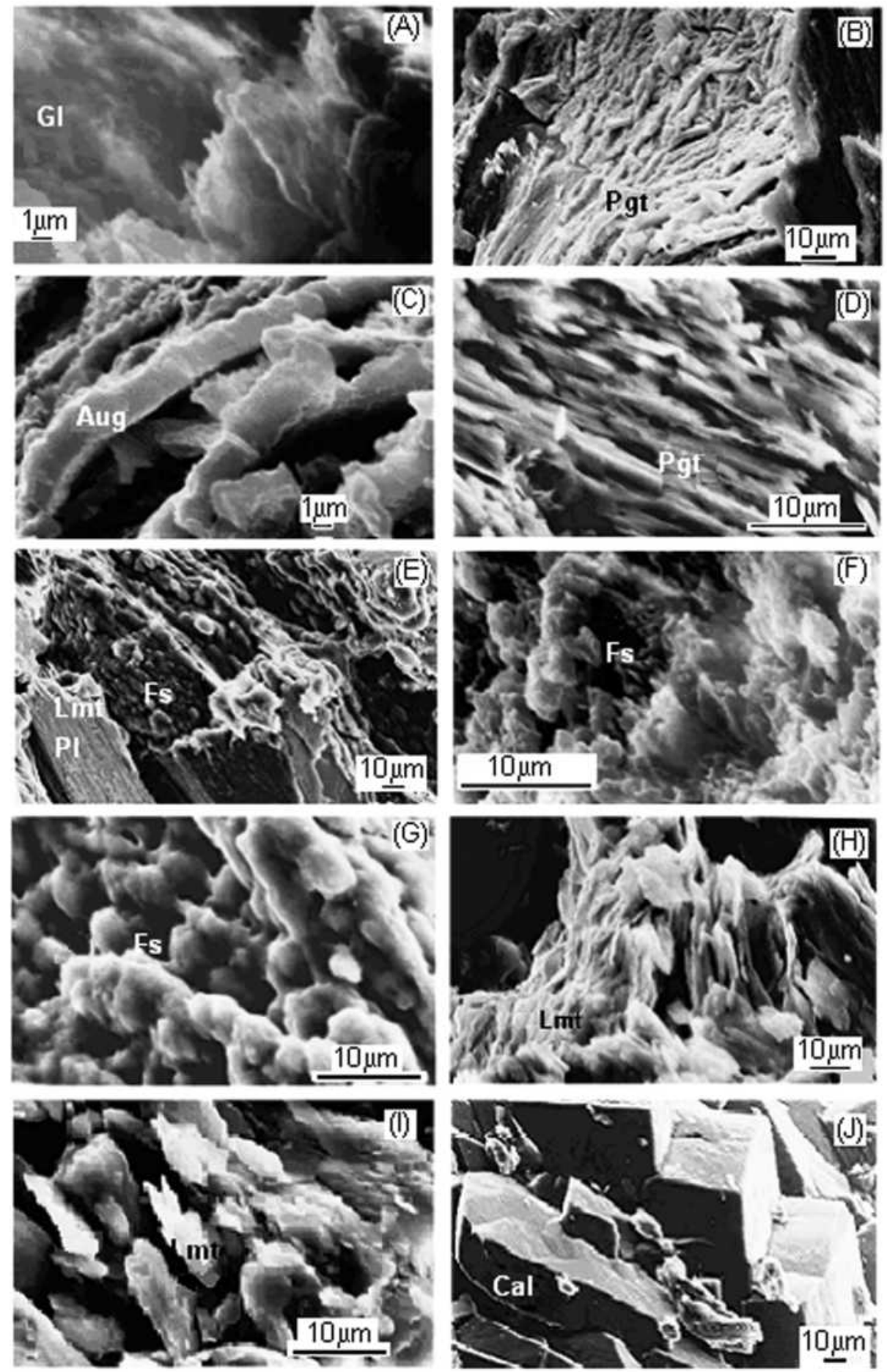

Figure 9. Scanning electron microscope images of glass fragments with crystals: (a) glass, (b) pigeonite in glass, (c) augite, (d) tabular pigeonite oriented along the $z$ axis, (e) prismatic ferrosilite and detrital plagioclase partially replaced by laumontite, (f) prismatic ferrosilite and hexagonal mazzite in glass, (g) ferrosilite and glass, (h) laumontite, (i) laumontite, (j) authigenic calcite. Compositions are indicated in Table 3. Identification of minerals is based on morphology and EDX analyses. SEM at $20 \mathrm{kV}$, dimensions in micrometers. shown in Table 4. The compositional data allow for the differentiation of glasses into two groups. The first, referred to as sodic, is represented by compositions M1 to M4 containing 71.80-77.77 wt \% $\mathrm{SiO}_{2}, \mathrm{Al}_{2} \mathrm{O}_{3} / \mathrm{SiO}_{2} 0.20$, with cations of low average field strength $\left(\mathrm{K}^{+} 0.52, \mathrm{Na}^{+} 0.96\right)$. The second group of non-sodic glasses include compositions M5 to M12, which contain 74.84-83.88 wt $\% \mathrm{SiO}_{2}$, $\mathrm{Al}_{2} \mathrm{O}_{3} / \mathrm{SiO}_{2} 0.11-0.16$, no $\mathrm{Na}_{2} \mathrm{O}$, and the highest concentration of high field strength cations $\left(\mathrm{Fe}^{2+} 4.81, \mathrm{Mg}^{2+} 3.86\right.$, and $\mathrm{Ca}^{2+}$ 2.04). Compositions M14 and M15 correspond to enstatite $+\mathrm{SiO}_{2}$ glass and rutile $+\mathrm{SiO}_{2}$ glass, respectively.
Major element variation diagrams for the sodic glasses, indicated in Figure 12, show that $\mathrm{Al}_{2} \mathrm{O}_{3}$ and $\mathrm{Na}_{2} \mathrm{O}$ decrease, $\mathrm{MgO}$ and $\mathrm{FeO}$ increase, and that there is little change in $\mathrm{CaO}$ and $\mathrm{K}_{2} \mathrm{O}$ as $\mathrm{SiO}_{2}$ increases from 71.80 to $77.77 \mathrm{wt} \%$. Similarly, the non-sodic glasses show decreasing $\mathrm{Al}_{2} \mathrm{O}_{3}$ and increasing $\mathrm{MgO}$. However, the non-sodic glasses differ from the sodic glasses in terms of decreasing $\mathrm{FeO}$ and $\mathrm{K}_{2} \mathrm{O}$ as $\mathrm{SiO}_{2}$ increases from 74.84 to $83.88 \mathrm{wt} \%$. Variation diagrams for alkalis vs. $\mathrm{SiO}_{2}$ indicate a steeper depletion of alkalis in sodic glasses than in the non-sodic, peraluminous glasses (Fig. 13). 
TABLE 3. Compositions of $\sim 10 \mu \mathrm{m}$ size crystalline minerals

\begin{tabular}{|c|c|c|c|c|c|c|c|c|c|c|c|c|}
\hline & $\begin{array}{c}1 \\
\text { Aug }\end{array}$ & $\begin{array}{c}2 \\
\text { Pgt }\end{array}$ & $\begin{array}{c}3 \\
\text { Pgt }\end{array}$ & $\begin{array}{c}4 \\
\text { Fs }\end{array}$ & $\begin{array}{c}5 \\
\text { Fs }\end{array}$ & $\begin{array}{c}6 \\
\text { Fs }\end{array}$ & $\begin{array}{c}7 \\
\text { Lmt }\end{array}$ & $\begin{array}{c}8 \\
\text { Lmt }\end{array}$ & $\begin{array}{c}9 \\
\text { LmtPI }\end{array}$ & $\begin{array}{c}10 \\
\mathrm{Mz}\end{array}$ & $\begin{array}{l}11 \\
\mathrm{PI}\end{array}$ & $\begin{array}{c}12 \\
\mathrm{MzGl}\end{array}$ \\
\hline $\mathrm{SiO}_{2}$ & 40.12 & 56.32 & 61.09 & 58.52 & 57.50 & 59.11 & 45.55 & 48.47 & 63.88 & 56.57 & 59.68 & 66.31 \\
\hline $\mathrm{Al}_{2} \mathrm{O}_{3}$ & 7.33 & 11.32 & 13.49 & 12.32 & 15.20 & 21.16 & 26.24 & 27.79 & 23.49 & 29.02 & 27.08 & 23.71 \\
\hline $\mathrm{TiO}_{2}$ & 0.10 & 0.32 & 0.13 & 0.02 & 0.07 & 0 & 0.02 & 0.02 & 0 & 0 & 0.01 & 0.13 \\
\hline $\mathrm{FeO}^{*}$ & 21.44 & 17.02 & 11.72 & 20.46 & 20.79 & 11.78 & 2.30 & 1.37 & 1.20 & 8.88 & 0.97 & 3.15 \\
\hline $\mathrm{MgO}$ & 8.37 & 8.39 & 9.30 & 3.50 & 1.43 & 2.18 & 2.78 & 3.28 & 0.42 & 2.69 & 0.44 & 0.98 \\
\hline $\mathrm{MnO}$ & 0.14 & 0.21 & 0.03 & 0.15 & 0 & 0.10 & 0 & 0 & 0 & 0 & 0.10 & 0.12 \\
\hline $\mathrm{CaO}$ & 20.80 & 5.31 & 3.45 & 3.92 & 3.75 & 3.40 & 15.78 & 12.66 & 10.12 & 1.94 & 6.79 & 0.45 \\
\hline $\mathrm{Na}_{2} \mathrm{O}$ & 1.69 & 0.68 & 0.72 & 1.02 & 1.24 & 1.79 & 0.89 & 1.12 & 0.63 & 0.71 & 4.48 & 0.89 \\
\hline $\mathrm{K}_{2} \mathrm{O}$ & 0.01 & 0.42 & 0.08 & 0.10 & 0.02 & 0.26 & 6.38 & 5.34 & 0.25 & 0.18 & 0.46 & 4.25 \\
\hline $\mathrm{Si}^{4+}$ & 1.63 & 2.03 & 2.10 & 2.11 & 2.07 & 2.04 & 13.22 & 13.68 & 16.80 & 22.78 & 2.64 & 1.45 \\
\hline $\mathrm{Al}^{3+}$ & 0.35 & 0.48 & 0.55 & 0.52 & 0.64 & 0.86 & 8.97 & 9.23 & 7.28 & 13.78 & 1.41 & 0.61 \\
\hline $\mathrm{Ti}^{4+}$ & 0.01 & 0.01 & 0.01 & 0 & 0 & 0 & 0 & 0 & 0 & 0 & 0 & 0 \\
\hline $\mathrm{Fe}^{2+*}$ & 0.73 & 0.51 & 0.34 & 0.62 & 0.63 & 0.34 & 0.56 & 0.32 & 0.26 & 2.99 & 0.04 & 0.06 \\
\hline $\mathrm{Mg}^{2+}$ & 0.51 & 0.45 & 0.48 & 0.19 & 0.08 & 0.11 & 1.20 & 1.38 & 0.16 & 1.61 & 0.03 & 0.03 \\
\hline $\mathrm{Mn}^{2+}$ & 0.01 & 0.01 & 0 & 0 & 0 & 0 & 0 & 0 & 0 & 0 & 0 & 0 \\
\hline $\mathrm{Ca}^{2+}$ & 0.90 & 0.20 & 0.13 & 0.15 & 0.14 & 0.13 & 4.90 & 3.82 & 2.85 & 0.84 & 0.32 & 0.01 \\
\hline $\mathrm{Na}^{+}$ & 0.13 & 0.05 & 0.05 & 0.07 & 0.09 & 0.12 & 0.50 & 0.61 & 0.32 & 0.55 & 0.38 & 0.04 \\
\hline $\mathrm{K}^{+}$ & 0 & 0.02 & 0.01 & 0.00 & 0.00 & 0.01 & 2.36 & 1.92 & 0.08 & 0.09 & 0.03 & 0.12 \\
\hline $\mathrm{O}^{2-}$ & 6.00 & 6.00 & 6.00 & 6.00 & 6.00 & 6.00 & 48.00 & 48.00 & 48.00 & 72.00 & 8.00 & 4.00 \\
\hline
\end{tabular}

Notes: $\mathrm{Aug}=$ augite, $\mathrm{Pgt}=$ pigeonite, $\mathrm{Fs}=$ ferrosilite, $\mathrm{Lmt}=$ laumontite, $\mathrm{LmtPI}=$ laumontite plagioclase, $\mathrm{Mz}=\mathrm{mazzite}, \mathrm{PI}=$ plagioclase, $\mathrm{MzGl}=\mathrm{mazzite}$ glass. Analyse by EDX on fragments selected using the SEM. Compositions in wt $\% ; \mathrm{FeO}^{*}$ is $\mathrm{Fe}^{2+}+\mathrm{Fe}^{3+}$.

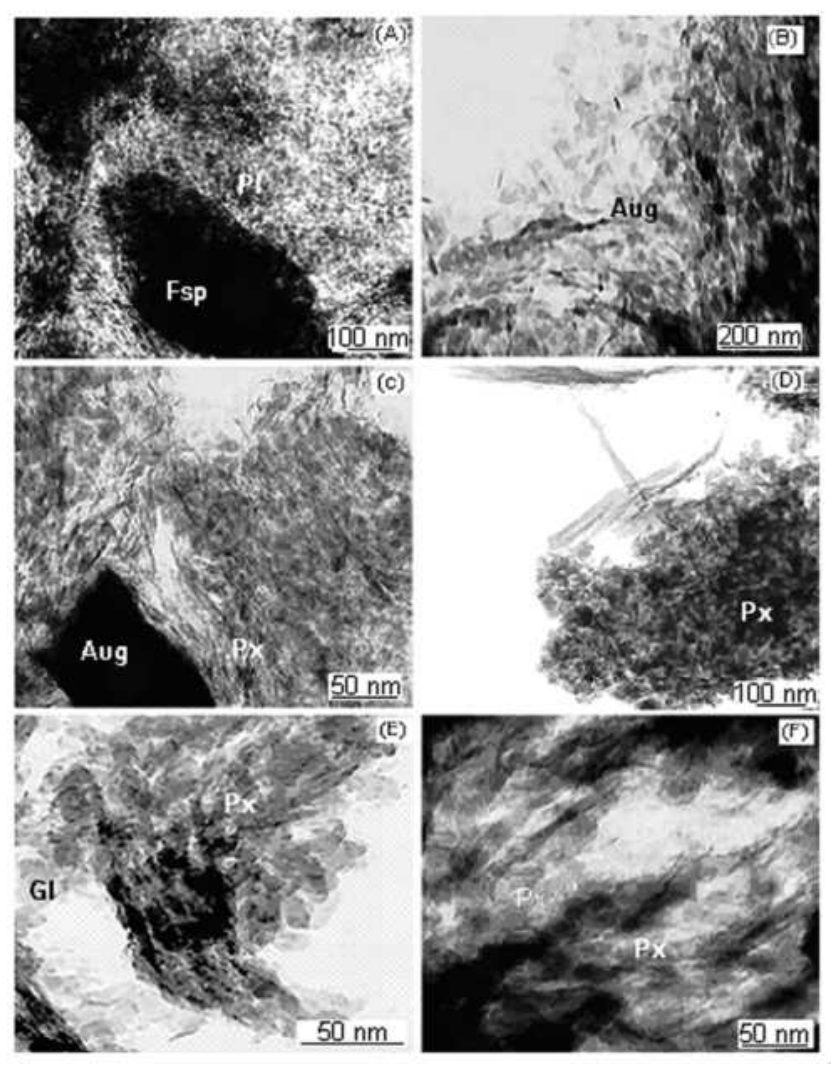

FIGURE 10. Scanning electron microscope images of glass fragments from tephra showing: (a) feldspar phenocryst dissolving in glass partially devitrified to microlithic plagioclase; (b) augite phenocryst fragmented to prismatic crystallites; (c) augite phenocryst in glass devitrified to pyroxene microcrystallites; (d) cryptocrystalline aggregate of prismatic and feathery pyroxene in glass; (e) glass devitrified and fragmented to tabular and prismatic pyroxene microcrystallites; (f) shard devitrified to tabular pyroxene, and covered by feathery pyroxene. SEM at accelerating voltage of $200 \mathrm{kV}$, system resolution $68 \mathrm{eV}$, dimensions in nanometers.
TABLE 4. Major element compositions of selected glasses

\begin{tabular}{|c|c|c|c|c|c|c|c|c|c|}
\hline & $\mathrm{SiO}_{2}$ & $\mathrm{Al}_{2} \mathrm{O}_{3}$ & $\mathrm{TiO}_{2}$ & $\mathrm{MgO}$ & $\mathrm{FeO}^{*}$ & $\mathrm{CaO}$ & $\mathrm{K}_{2} \mathrm{O}$ & $\mathrm{Na}_{2} \mathrm{O}$ & \\
\hline Tephra* & 77.20 & 10.73 & 0.43 & 3.82 & 3.20 & 2.39 & 1.30 & 0.92 & \\
\hline M1 & 73.80 & 17.19 & 0.29 & 0.68 & 1.20 & 1.54 & 1.37 & 5.93 & \\
\hline M2 & 75.36 & 16.25 & 0 & 1.99 & 1.77 & 1.73 & 1.18 & 1.72 & \\
\hline M3 & 75.59 & 15.61 & 0 & 1.64 & 2.17 & 1.73 & 1.11 & 1.64 & \\
\hline M4 & 77.77 & 12.34 & 0 & 2.20 & 2.39 & 1.30 & 1.43 & 2.56 & \\
\hline M5 & 75.84 & 13.44 & 0 & 4.49 & 3.91 & 1.18 & 1.14 & 0 & \\
\hline M6 & 75.94 & 10.26 & 0 & 5.43 & 5.54 & 1.21 & 1.62 & 0 & \\
\hline M7 & 80.45 & 10.32 & 0 & 3.41 & 2.95 & 1.43 & 0.71 & 0.74 & \\
\hline M8 & 80.98 & 8.88 & 0 & 4.11 & 3.68 & 1.83 & 0.51 & 0 & \\
\hline M9 & 81.33 & 9.84 & 0 & 3.75 & 2.76 & 1.01 & 1.31 & 0 & \\
\hline M10 & 81.52 & 9.46 & 0 & 3.75 & 2.55 & 1.39 & 1.33 & 0 & \\
\hline M11 & 82.23 & 8.76 & 0 & 3.63 & 3.31 & 1.33 & 0.74 & 0 & \\
\hline M12 & 83.88 & 7.69 & 0 & 3.94 & 2.31 & 1.24 & 0.8 & 0.58 & \\
\hline M13 & 83.88 & 7.46 & 0 & 4.03 & 1.61 & 1.38 & 0.50 & 0 & \\
\hline M14 & 75.78 & 0.00 & 0 & 22.84 & 0.00 & 1.38 & 0.00 & 0 & \\
\hline \multirow[t]{2}{*}{ M15 } & 28.18 & 2.90 & 63.28 & 0.90 & 4.03 & 0.71 & 0.00 & 0 & \\
\hline & $\mathrm{Si}^{4+}$ & $\mathrm{Al}^{3+}$ & $\mathrm{Ti}^{4+}$ & $\mathrm{Mg}^{2+}$ & $\mathrm{Fe}^{2+}$ & $\mathrm{Ca}^{2+}$ & $\mathrm{K}^{+}$ & $\mathrm{Na}^{+}$ & $\mathrm{O}^{2-}$ \\
\hline Tephra & 1.65 & 0.27 & 0.01 & 0.12 & 0.06 & 0.05 & 0.04 & 0.04 & 4.00 \\
\hline M1 & 1.55 & 0.44 & 0 & 0.02 & 0.02 & 0.04 & 0.0 & 0.25 & 4.00 \\
\hline M2 & 1.60 & 0.41 & 0 & 0.06 & 0.03 & 0.04 & 0.03 & 0.07 & 4.00 \\
\hline M3 & 1.60 & 0.39 & 0 & 0.07 & 0.03 & 0.04 & 0.03 & 0.07 & 4.00 \\
\hline M4 & 1.65 & 0.31 & & 0.07 & 0.04 & 0.03 & 0.04 & 0.11 & 4.00 \\
\hline M5 & 1.62 & 0.34 & 0 & 0.14 & 0.07 & 0.03 & 0.03 & 0 & 4.00 \\
\hline M6 & 1.63 & 0.26 & 0 & 0.17 & 0.09 & 0.03 & 0.04 & 0 & 4.00 \\
\hline M7 & 1.69 & 0.26 & 0 & & 0.05 & 0.0 & 0.0 & 0.03 & 4.00 \\
\hline M8 & 1.71 & 0.22 & 0 & 0.13 & 0.06 & 0.04 & 0.01 & 0 & 4.00 \\
\hline M9 & 1.71 & 0.24 & 0 & 0.12 & 0.04 & 0.02 & 0.03 & & 4.00 \\
\hline M10 & 1.72 & 0.23 & 0 & 0.12 & 0.04 & 0.03 & 0.04 & 0.01 & 4.00 \\
\hline M11 & 1.72 & 0.22 & 0 & 0.11 & 0.05 & 0.03 & 0.02 & 0 & 4.00 \\
\hline M12 & 1.74 & 0.19 & 0 & 0.12 & 0.04 & 0.03 & 0.02 & 0.02 & 4.00 \\
\hline M13 & 1.74 & 0.18 & 0.02 & 0.12 & 0.03 & 0.03 & 0.01 & 0 & 4.00 \\
\hline M14 & 1.62 & 0.00 & 0 & 0.73 & 0.00 & 0.03 & 0.00 & 0 & 4.00 \\
\hline M15 & 0.69 & 0.08 & 1.17 & 0.03 & 0.07 & 0.02 & 0.00 & 0 & 4.00 \\
\hline
\end{tabular}

${ }^{*}$ Analysis by XRF on bulk tephra, others by EDX on fragments selected by SEM. $\mathrm{FeO}^{*}$ is $\mathrm{Fe}^{2+}+\mathrm{Fe}^{3+}$. Compositions are in $\mathrm{wt} \%$.

Less than $2 \%$ of the tephra consists of $\sim 10 \mu \mathrm{m}$ sized crystals of pyroxenes, plagioclase, and zeolites. The pyroxenes are aluminous augite with composition $\left(\mathrm{Si}_{1.63} \mathrm{Al}_{0.35} \mathrm{Ti}_{0.01}\right)\left(\mathrm{Mg}_{0.50} \mathrm{Fe}_{0.50}\right)$ $\left(\mathrm{Fe}_{0.22} \mathrm{Ca}_{0.90} \mathrm{Na}_{0.13}\right) \mathrm{O}_{6}$ and aluminous pigeonite with composition $\left(\mathrm{Si}_{2.03}\right)\left(\mathrm{Al}_{0.48} \mathrm{Fe}_{0.52}\right)\left(\mathrm{Fe}_{0.04} \mathrm{Mg}_{0.45} \mathrm{Ca}_{0.20} \mathrm{Na}_{0.05} \mathrm{~K}_{0.02} \square_{0.27}\right) \mathrm{O}_{6}$. This assemblage of high- and low-Ca pyroxene compositions is indicative of rapid crystallization from a high- $\mathrm{Al}_{2} \mathrm{O}_{3}$ melt (Table 3). A third pyroxene is aluminous ferrosilite with com- 

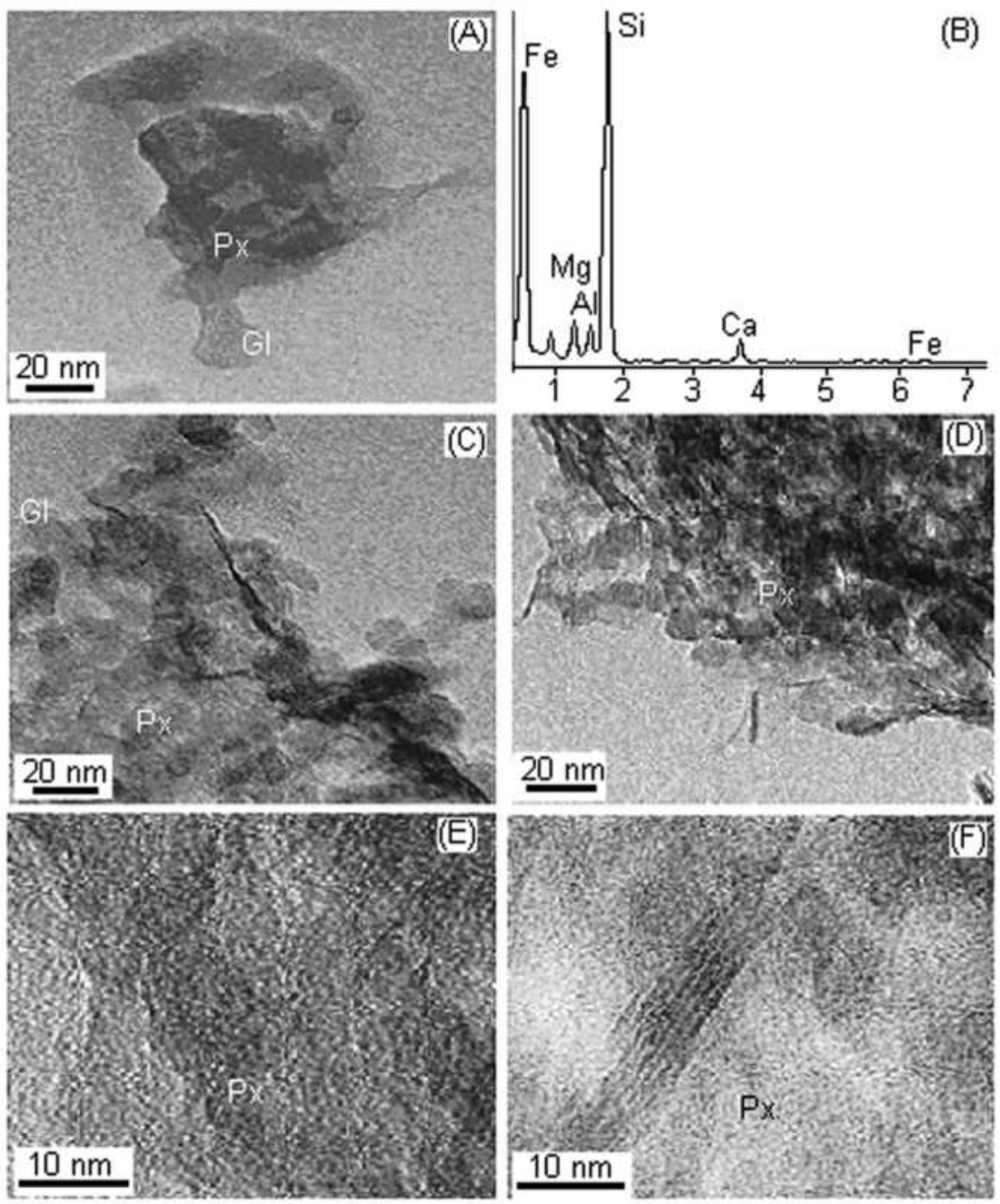

FiguRE 11. Transmission electron microscope images of glass fragments from tephra showing: (a) pyroxene crystals in a glass bubble; (b) EDX profile of sample A; (c) pyroxene crystals in soldered glass drops; (d) prismatic and feathery pyroxene in soldered glass drops; (e) lamination in prismatic pyroxene; (f) image of the 100 prism of pyroxene showing uninterrupted amphibole chains between pyroxene chains, with the $c$-dimension $5.23 \AA$ transverse to the long $y$-axis of the crystal. TEM at accelerating voltage of $300 \mathrm{kV}$, dimensions in nanometers. position $\left(\mathrm{Si}_{2.07}\right)\left(\mathrm{Al}_{0.64} \mathrm{Fe}_{0.36}\right)\left(\mathrm{Fe}_{0.33} \mathrm{Mg}_{0.08} \mathrm{Ca}_{0.14} \mathrm{Na}_{0.09} \square_{0.36}\right) \mathrm{O}_{6}$ and a $\mathrm{Mg} /(\mathrm{Mg}+\mathrm{Fe}+\mathrm{Ca})$ ratio lower than the 0.20 stability limit below which ferrosilite transforms to fayalite $+\mathrm{SiO}_{2}$, and is indicative of crystallization at elevated temperatures and stabilization (Huebner 1980; Lindsley 1980). Plagioclase is labradorite with $\mathrm{An}_{63} \mathrm{Ab}_{27}$. Among the zeolites present, laumontite with compositions $\left(\mathrm{Si}_{3.30} \mathrm{Al}_{0.24} \square_{0.46}\right) \mathrm{Al}_{2.00} \mathrm{Ca}\left(\mathrm{Ca}_{0.22} \mathrm{Mg}_{0.30} \mathrm{Fe}_{0.14}^{2+} \mathrm{Na}_{0.12} \mathrm{~K}_{0.59}\right) \mathrm{O}_{12}$ and $\left(\mathrm{Si}_{3.42} \mathrm{Al}_{0.31} \square_{0.27}\right) \mathrm{Al}_{2.00}\left(\mathrm{Ca}_{0.95} \mathrm{Mg}_{0.03} \mathrm{Fe}_{0.08}^{2+}\right)\left(\mathrm{Mg}_{0.31} \mathrm{Na}_{0.15} \mathrm{~K}_{0.48}\right) \mathrm{O}_{12}$ contain unusually high contents of $\mathrm{Mg}, \mathrm{Fe}, \mathrm{Na}$, and $\mathrm{K}$ that suggest contamination from the surrounding glass. The laumontite occurs in single and parallel oriented crystals $\sim 10 \mu \mathrm{m}$ in size in glass. Crystals may have formed during the last cooling stages of the residual non-sodic melt and as an alteration product of plagioclase, characterized by $\mathrm{R} 0.63$ [ratio $\mathrm{Si} /(\mathrm{Si}+\mathrm{Al})]$, dominant exchange cation (DEC) Ca, alkali ratios $\mathrm{Na} /(\mathrm{Na}+\mathrm{Ca}$ ) of 0.17 and 0.24 , and excess extra framework cations 1.37 and 0.94 possibly located on extended framework cation sites (Armbruster and Gunter 2001; Passaglia and Sheppard 2001). Mazzite of compositions $\left(\mathrm{Si}_{22.79} \mathrm{Al}_{13.76}\right)\left(\mathrm{Mg}_{1.61} \mathrm{Fe}_{2.99} \mathrm{Ca}_{0.84} \mathrm{Na}_{0.55} \mathrm{~K}_{0.09}\right) \mathrm{O}_{72}$ and $\left(\mathrm{Si}_{26.10} \mathrm{Al}_{10.98}\right)\left(\mathrm{Mg}_{0.57} \mathrm{Fe}_{1.03} \mathrm{Ca}_{0.19} \mathrm{Na}_{0.68} \mathrm{~K}_{2.13} \square_{1.40}\right) \mathrm{O}_{72}$ crystallizes as hexagonal prisms secondary to alkali-rich glass, has R 0.62 and 0.70 , DEC Mg, alkali ratio of 0.24 , and channel cations 6.08 and 4.6 (Table 3) (Galli et al. 1974).

\section{DISCUSSION}

Ninety-eight percent of the tephra is compositionally heterogeneous silicoaluminate glass comprised of sodic and nonsodic compositions, in addition to the variations resulting from the fractional crystallization of their corresponding magmas (Table 4). The compositional variations shown in Figure 12 and described above imply that sodic glasses suggest crystallization of plagioclase. On the other hand, the compositional variations in non-sodic glasses suggest crystallization of $\mathrm{Ca}$-plagioclase and pyroxene. Sodic and non-sodic glasses share common compositional trends of $\mathrm{Al}_{2} \mathrm{O}_{3}, \mathrm{MgO}, \mathrm{CaO}$, and $\mathrm{K}_{2} \mathrm{O}$ and contrast with $\mathrm{FeO}$, with crystal formation at different rates.

The compositions of crystals and glasses were determined using SEM and EDX of selected fragments with the difficulties in precision related to crystal size and association with glass. To better visualize the compositional variation of glasses and to ascertain crystallization paths, we refer to their normative compositions (Table 5) calculated from the CIPW norm (Best 1982). Tephra and glasses show highly evolved compositions with differentiation indices (DI) higher than 50. Among the sodic glasses (M1 to M4), M1 has 57.8\% normative plagioclase $\left(\mathrm{An}_{13} \mathrm{Ab}_{87}\right)$ that evolves to $18.1 \%\left(\mathrm{An}_{22} \mathrm{Ab}_{78}\right)$ in glass M4. Normative hypersthene increases from $3.4 \%\left(\mathrm{En}_{50} \mathrm{Fe}_{50}\right)$ to $9.9 \%\left(\mathrm{En}_{62} \mathrm{Fe}_{38}\right)$. The liquidus 

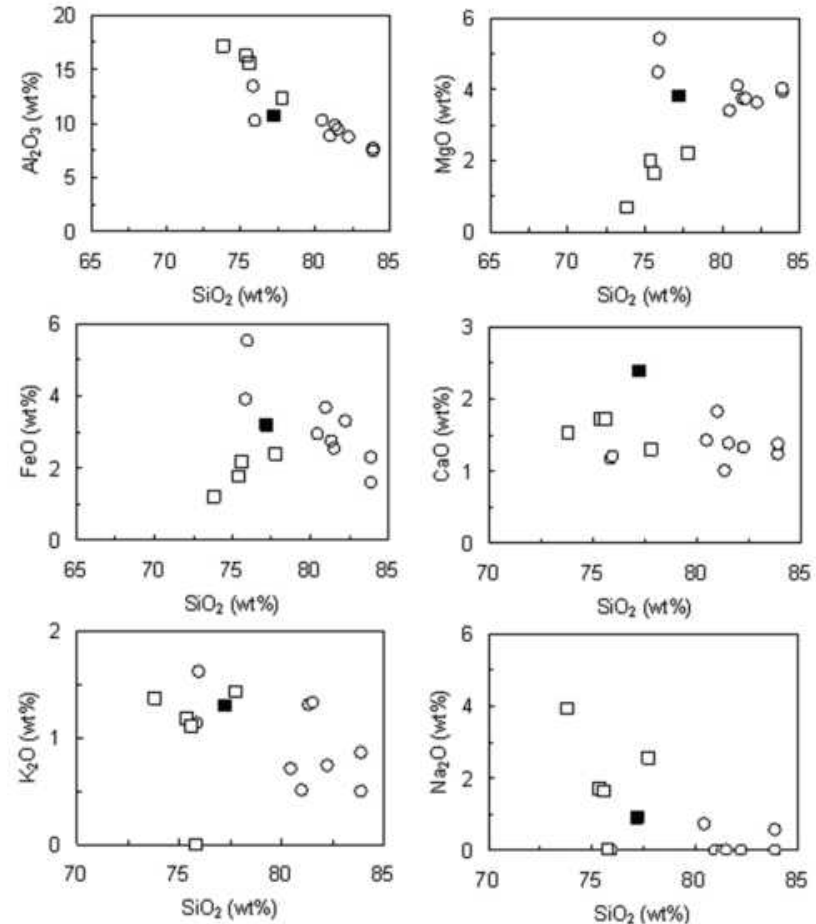

FIGURE 12. Variation diagrams of major elements vs. $\mathrm{SiO}_{2}$ of tephra and glasses. Sodic glasses containing between 71.80 and $77.77 \mathrm{wt} \%$ $\mathrm{SiO}_{2}$ show descending trends of $\mathrm{Al}_{2} \mathrm{O}_{3}$ and $\mathrm{Na}_{2} \mathrm{O}$, ascending $\mathrm{MgO}$ and $\mathrm{FeO}$, and $\mathrm{CaO}$ and $\mathrm{K}_{2} \mathrm{O}$ are ambiguous. Sodium-free glasses extending from 74.84 to 83.88 wt $\% \mathrm{SiO}_{2}$ show a decrease in $\mathrm{MgO}, \mathrm{FeO}, \mathrm{CaO}$, and $\mathrm{K}_{2} \mathrm{O}$. EDX analyses of fragments selected by SEM. Symbols: filled squares $=$ bulk tephra; open squares $=$ sodic glasses; open circles $=$ non-sodic glasses.

TABLE 5. CIPW normative minerals of tephra and glasses

\begin{tabular}{llllllllll}
\hline & Qtz & Or & An & Ab & En & Fe & LT & Vis & DI \\
\hline Tephra & 53.71 & 7.68 & 10.98 & 7.66 & 9.98 & 4.70 & 715 & 11.4 & 81 \\
M1 & 27.28 & 8.10 & 7.23 & 50.59 & 1.72 & 1.70 & 814 & 9.3 & 93 \\
M2 & 52.69 & 6.97 & 8.26 & 14.88 & 5.48 & 2.73 & 749 & 11.8 & 83 \\
M3 & 54.08 & 6.62 & 8.31 & 14.28 & 4.66 & 3.45 & 737 & 12.2 & 83 \\
M4 & 49.35 & 8.45 & 3.95 & 14.16 & 6.13 & 3.74 & 704 & 12.1 & 86 \\
M5 & 58.99 & 6.74 & 5.85 & 0.00 & 12.34 & 6.02 & 740 & 11.3 & 72 \\
M6 & 54.42 & 9.57 & 6.00 & 0.00 & 15.07 & 8.63 & 738 & 10.2 & 70 \\
M7 & 62.80 & 4.20 & 6.89 & 6.47 & 9.36 & 4.55 & 656 & 13.5 & 80 \\
M8 & 65.91 & 3.01 & 9.08 & 0.00 & 11.32 & 5.67 & 645 & 13.4 & 78 \\
M9 & 66.25 & 7.74 & 5.01 & 0.00 & 10.20 & 4.21 & 639 & 14.1 & 79 \\
M10 & 65.73 & 7.86 & 6.90 & 0.00 & 10.15 & 3.87 & 636 & 14.1 & 80 \\
M11 & 68.37 & 4.37 & 6.60 & 0.00 & 10.01 & 5.11 & 623 & 14.4 & 79 \\
M12 & 66.39 & 5.08 & 5.95 & 5.06 & 10.52 & 3.47 & 600 & 14.6 & 83 \\
M13 & 72.45 & 3.01 & 6.95 & 0.00 & 10.75 & 2.41 & 575 & 15.9 & 82 \\
\hline Mote: LT $=$ liquidus temperature & &
\end{tabular}

Note: $\mathrm{LT}=$ liquidus temperature, $\mathrm{Vis}=$ viscosity, $\mathrm{DI}=$ differentiation index

temperature descends from 814 to $704{ }^{\circ} \mathrm{C}$, suggesting crystallization of Ca-plagioclase to Na-plagioclase and increasingly ferrous pyroxene in progressively more siliceous glass. Glasses M7 and M12 are siliceous, with composition M12 corresponding to $11.0 \%$ normative plagioclase $\left(\mathrm{An}_{54} \mathrm{Ab}_{46}\right)$ and $14 \%$ hypersthene $\left(\mathrm{En}_{75} \mathrm{Fe}_{25}\right)$. Glasses M5 and M6 are sodium-free glasses with normative hypersthene $\left(\mathrm{En}_{65} \mathrm{Fe}_{35}\right)$ and anorthite. These glasses are characterized by low viscosity, a liquidus temperature of $739^{\circ} \mathrm{C}$ (within the same range as sodic glass M2), and a differentiation index of 71. Glasses M8 to M11 and M13 correspond to sodium free glasses of normative 9.1 to $6.9 \%$ anorthite and hypersthene
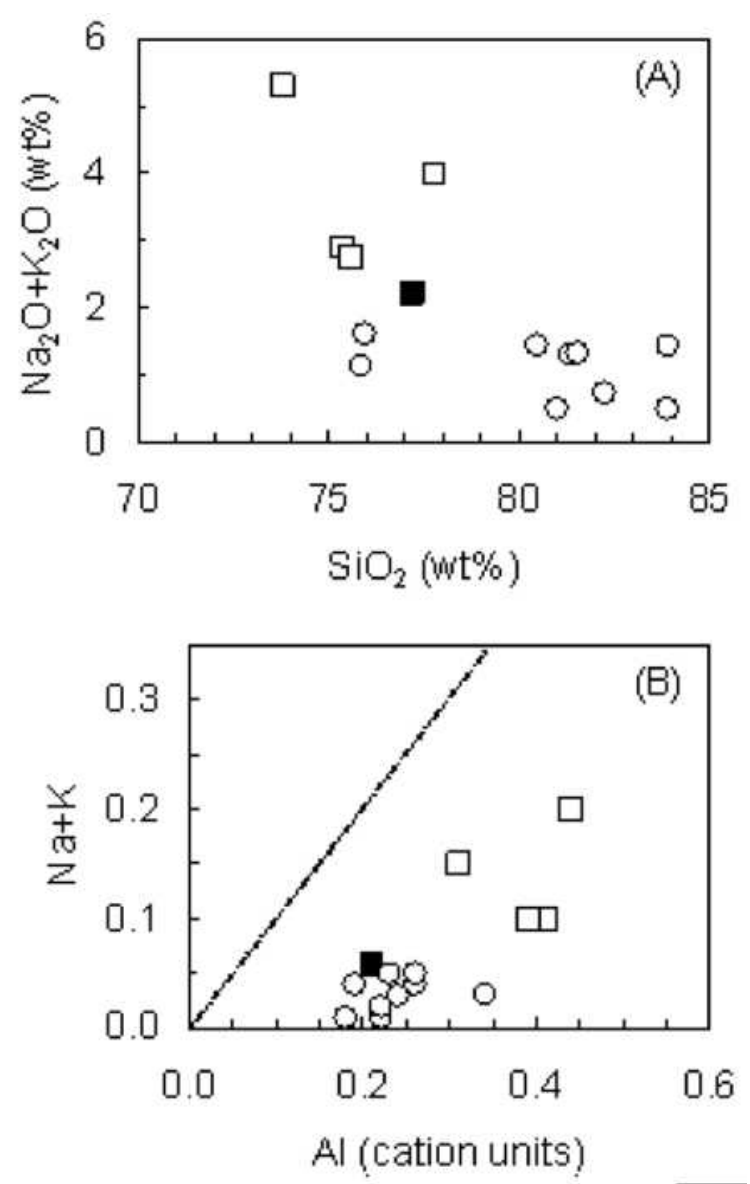

FIGURE 13. Total alkalis vs. $\mathrm{SiO}_{2}$ (a) and total alkalis vs. $\mathrm{Al}$ (b) indicate steep depletion in alkalinity of sodic glasses associated with crystallization of sodic plagioclase, relative to the slower reduction of $\mathrm{K}_{2} \mathrm{O}$ from Na-free glasses. Glasses have peraluminous compositions. Analyses by SEM and EDX of selected fragments. Symbols: filled squares $=$ bulk tephra; open squares $=$ sodic glasses; open circles $=$ non-sodic glasses.

$\left(\mathrm{En}_{67} \mathrm{Fe}_{33}, \mathrm{En}_{71} \mathrm{Fe}_{29}, \mathrm{En}_{72} \mathrm{Fe}_{28}, \mathrm{En}_{66} \mathrm{Fe}_{34}\right.$, and $\mathrm{En}_{82} \mathrm{Fe}_{18}$, respectively) in increasingly more siliceous melts with the liquidus temperature descending from 739 to $575^{\circ} \mathrm{C}$ and differentiation index ascending from 78 to a highly evolved 85 . In the systems albite-orthoclase-anorthite and albite-anorthite-hypersthene, sodic glasses have albitic compositions different from those of non-sodic glasses that are richer in normative hypersthene, anorthite, and orthoclase (Fig. 14).

Glass M1 (Table 4), with the lowest content of $\mathrm{SiO}_{2}, \mathrm{MgO}$, and $\mathrm{FeO}$, highest $\mathrm{Al}_{2} \mathrm{O}_{3}$ and $\mathrm{Na}_{2} \mathrm{O}$, and estimated nominal liquidus temperature of $814^{\circ} \mathrm{C}$, may have the composition closest to the precursor magma. The magma evolved from M1 to M4 upon cooling, becoming enriched in $\mathrm{SiO}_{2}, \mathrm{MgO}$, and $\mathrm{FeO}$ and depleted in $\mathrm{Al}_{2} \mathrm{O}_{3}, \mathrm{CaO}$, and $\mathrm{Na}_{2} \mathrm{O}$, crystallizing - as estimated from the CIPW calculations - from bytownite to labradorite, which compare favorably with experimentally determined labradorite $\left(\mathrm{An}_{63} \mathrm{Ab}_{37}\right)$ (composition 11 in Table 3). Crystallization ceases at the normative liquidus temperature of $704{ }^{\circ} \mathrm{C}$ with the final residual melt represented by glass $\mathrm{M} 4$ with $77.77 \mathrm{wt} \% \mathrm{SiO}_{2}$.

A second Na-free magma, represented by glasses M5 and M6, 

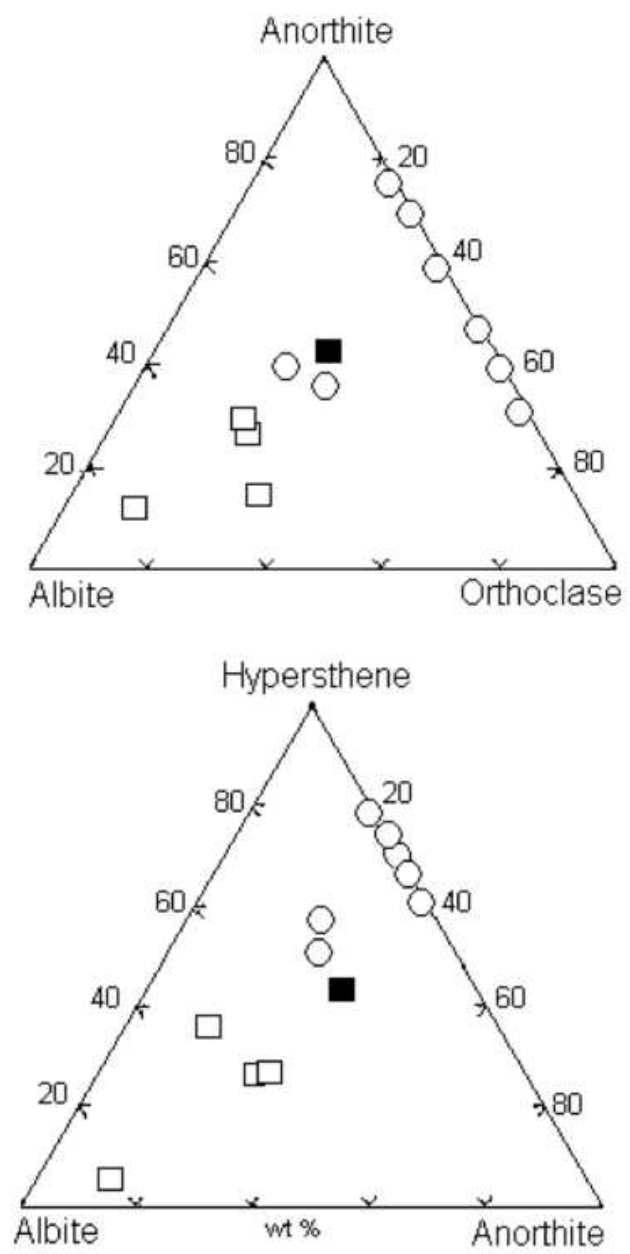

FIGURE 14. Normative compositions of tephra and glasses. Sodic glasses have albitic compositions compared with non-sodic glasses that remain within the hypersthene-anorthite system. Symbols: filled squares $=$ bulk tephra; open squares $=$ sodic glasses; open circles $=$ non-sodic glasses.

evolves upon cooling, through compositions M7 to M13, to a highly siliceous glass with $83.88 \mathrm{wt} \% \mathrm{SiO}_{2}$ and normative liquidus temperature $575^{\circ} \mathrm{C}$ (Table 4). Glasses M5 and M6 have liquidus temperatures and contents of $\mathrm{SiO}_{2}$ and $\mathrm{Al}_{2} \mathrm{O}_{3}$ approximately equal to those of sodic glasses M2 and M3, suggesting possible simultaneous crystallization of both magmas starting at around $739^{\circ} \mathrm{C}$. Crystallization of the Na-free magma - as estimated from the normative calculations - began with high-Mg, low-Fe pyroxene and ended with low-Mg, high-Fe pyroxene $+\mathrm{Ca}$-plagioclase. The Na-free magma crystallized a comparatively larger amount of pyroxene with a dominant ferrosilite component and a lower amount of labradorite (from samples M7 and M12) in highly siliceous glass than the Na glasses. The latter crystallized more sodic plagioclase and less pyroxene in less siliceous glass.

Analyzed phenocrysts have compositions of aluminous labradorite, augite $\left(\mathrm{En}_{41} \mathrm{Fe}_{59}\right)$, pigeonite $\left(\mathrm{En}_{47} \mathrm{Fe}_{59}\right.$ and $\left.\mathrm{En}_{58} \mathrm{Fe}_{42}\right)$, and ferrosilite $\left(\mathrm{En}_{9} \mathrm{Fe}_{81}\right.$ and $\left.\mathrm{En}_{24} \mathrm{Fe}_{76}\right)$ (Table 3) similar to those estimated from the CIPW norm in predominantly Na-free glasses. The cooling path and crystallization were likely in equilibrium (Osborn and Muan 1960; Morse 1980). Glasses M12 and M13 correspond to the lowest temperature residual melt with $83.88 \mathrm{wt} \% \mathrm{SiO}_{2}$. Limited formation of pyroxene and plagioclase in amounts less than those anticipated from the normative calculations could indicate rapid cooling and solidification of magma, associated with a fast reduction in pressure, temperature, and water vapor and poor development of the glass framework.

Analyzed and normative data have indicated that solidification and crystallization of sodic and non-sodic magmas started $\sim 739^{\circ} \mathrm{C}$ or above and ended $\sim 575^{\circ} \mathrm{C}$. Sodic residual magma M4 solidified at the normative liquidus temperature of $704^{\circ} \mathrm{C}$, whereas non-sodic magma $\mathrm{M} 13 \mathrm{did}$ so at $575^{\circ} \mathrm{C}$. Both temperatures are above the stability limits of the zeolites laumontite and mazzite recognized in tephra in amounts $<1 \mathrm{vol} \%$. Compositional data for crystalline minerals and glasses (Tables 3 and 4; Figs. 12 and 13) indicate that the two magmatic processes of crystal fractionation were overlapped by a later process of secondary low-grade metamorphism on the glasses by fluids, leading to crystallization of mazzite from the less siliceous sodic glasses, laumontite from the more silicic non-sodic glasses, and authigenic laumontite from Ca-plagioclase and calcite. In the presence of abundant water, water diffused into the glass would have forced cations outward, modified Al-O bonds, and de-polymerized the glass structural network, forming $\mathrm{SiOH}, \mathrm{AlOH}$, and $\mathrm{Si}-\mathrm{O}-\mathrm{T}$ bonds (Mungall and Martin 1994; Slejko et al. 2004).

SEM and TEM studies allowed for the recognition of glasses of distinct compositions and fluidity and their devitrification to fine-grained, well-formed crystallites ( $<5 \mathrm{~nm}$ in size) of plagioclase and pyroxene. These crystallites are not hydratable, nor are the larger $\sim 10 \mu \mathrm{m}$ crystals of plagioclase and pyroxenes observed by SEM at $20 \mathrm{kV}$. Only a minor fraction (less than $2 \%$, of $\sim 10$ $\mu \mathrm{m}$ size crystals) of low-grade metamorphic laumontite and mazzite adsorb water. Crystallization of magmatic laumontite is not evident from the SEM studies. The minor abundance of laumontite and mazzite does not justify the intense dehydration shown by tephra.

As described above, tephra loses $12.63 \mathrm{wt} \%$ adsorbed water reversibly by heating to $72{ }^{\circ} \mathrm{C}$ and $0.57 \mathrm{wt} \%$ is lost from hydroxyls and water by heating to $454^{\circ} \mathrm{C}$. Weak endothermic reactions at 645 and $952{ }^{\circ} \mathrm{C}$ are caused by structural accommodations or by additional minor losses of water and hydroxyls. Although strong dehydration and thermal behavior resemble characterisitics of zeolite minerals, their presence is further discounted by the fact that a dehydration loss of $12.63 \mathrm{wt} \% \mathrm{H}_{2} \mathrm{O}$ would correspond to an estimated content of $78 \mathrm{wt} \%$ fully hydrated laumontite $\mathrm{CaAl}_{2} \mathrm{Si}_{4} \mathrm{O}_{12} \cdot 4.5 \mathrm{H}_{2} \mathrm{O}$ in the tephra (Fridriksson et al. 2003a). Such amounts would have been unmistakably recognized by XRD. However, the XRD data does not record the presence of laumontite or any other zeolite. The dehydration/hydration of the tephra at $72{ }^{\circ} \mathrm{C}$ is fully reversible even after heating to $500{ }^{\circ} \mathrm{C}$. Laumontite, when heated from 25 to $270{ }^{\circ} \mathrm{C}$, loses water from sites $\mathrm{W} 1$, W5, and $\mathrm{W} 2$ and between 300 and $400{ }^{\circ} \mathrm{C}$, loses half of the water in W8 sites, collapsing its structure irreversibly (Fridriksson et al. 2003a, 2003b; van Reeuwijk 1974; Armbruster and Kohler 1992; Stahl et al. 1996; Bish and Carey 2001).

The intense hydration/dehydration of the tephra is attributed to the glass, which is its principal component. Vibrational spectra have shown that molecular water $\mathrm{H}_{2} \mathrm{O}_{\mathrm{m}}$ is the principal adsorbate, predominating over hydroxyls $\mathrm{OH}$. Molecular $\mathrm{H}_{2} \mathrm{O}_{m}$ 
occurs as Type I(A) molecules vibrating freely in interstitial sites, Type I(B) molecules H-bonded to silanol groups in the glass network, silanols H-bonded to oxygen of neighboring Type III $\mathrm{H}_{2} \mathrm{O}_{\mathrm{m}}$ molecules, Type II molecules bound to the silica network, and free $\mathrm{H}_{2} \mathrm{O}_{\mathrm{m}}$ hydrogen bonded to $\mathrm{H}_{2} \mathrm{O}_{\mathrm{m}}$ Type $\mathrm{I}(\mathrm{A})$ molecules inside the glass. The higher absorbance of the $3472.94 \mathrm{~cm}^{-1}$ band caused by motions of Type $\mathrm{II}_{2} \mathrm{O}_{\mathrm{m}}$ molecules bound to the silica network, relative to the lower absorbance $3624.83 \mathrm{~cm}^{-1}$ shoulder from $\mathrm{OH}$ motions, establishes the predominance of molecular $\mathrm{H}_{2} \mathrm{O}_{\mathrm{m}}$ and low-temperature hydration of glass. Hydration at high temperatures and partial water pressures would have incorporated less $\mathrm{H}_{2} \mathrm{O}_{\mathrm{m}}$ and more hydroxyls $\mathrm{OH}$ in the glass. The low-absorbance band at $5230.22 \mathrm{~cm}^{-1}$ (Fig. 7) that adds contributions from $\mathrm{HOH}$ motions $\mathrm{v}_{\mathrm{B}}\left(\mathrm{H}_{2} \mathrm{O}\right)+\mathrm{v}_{\mathrm{S}}\left(\mathrm{H}_{2} \mathrm{O}\right)$ of molecular water $\mathrm{H}_{2} \mathrm{O}_{\mathrm{m}}$ (Stolper 1982; Davis and Tomozawa 1996), and the absence of the $\sim 4520 \mathrm{~cm}^{-1}$ signal due to $\mathrm{XOH}$ bending plus stretching, confirms the predominance of molecular water $\mathrm{H}_{2} \mathrm{O}_{\mathrm{m}}$ over hydroxyls $\mathrm{OH}$ associated with the glass.

Adsorption by the glass is linked to its surface activity. NMR studies have indicated that ${ }^{27} \mathrm{Al}$ is predominantly in the form of ${ }^{\mathrm{IV}} \mathrm{Al}$ and some is present as ${ }^{\mathrm{V}} \mathrm{Al}$, possibly developed by reactions between polymerized tetrahedral and single tetrahedra terminating in NBOs (Topliss et al. 1997a, 1997b, 2000; Neuville et al. 2004, 2007; Allwardt et al. 2005a, 2005b, 2007). ${ }^{\mathrm{IV}} \mathrm{Al}$ and ${ }^{\mathrm{V}} \mathrm{Al}$ contribute to the surface activity of the glass by generating NBOs from reaction of $\mathrm{AlO}_{4}$ to configurations of $\mathrm{AlO}_{6}$ and $\mathrm{AlO}_{5}$ or ${ }^{\mathrm{V}} \mathrm{Al}-\mathrm{O}-{ }^{\mathrm{IV}} \mathrm{Si}$ and ${ }^{\mathrm{VI}} \mathrm{Al}-\mathrm{O}-{ }^{\mathrm{IV}} \mathrm{Si}$ in the magma at extreme conditions of $2500 \mathrm{~K}$ and 2-8 GPa (Poe et al. 1994; Stebbins 1995; Lee 2004; Allwardt et al. 2005a, 2005b, 2007), and from the replacement of ${ }^{\mathrm{VI}} \mathrm{Al}$ by $\mathrm{Mg}^{2+}$ and $\mathrm{Fe}^{2+}$ of high electrostatic charge and field strength (Cormier et al. 2003; Neuville et al. 2007).

Non-bridging oxygens could additionally result from low concentrations of $\mathrm{Na}$ in the sodic glasses and $\mathrm{Ca}$ in the non-sodic glasses, which are insufficient to charge balance Al, develop Al-O-Na and Al-O-Ca bonds, polymerize the glass, and impart chemical and physical stability (Cormier et al. 2003; Angeli et al. 2007). Their limited availability to compensate Al would develop Al-O bonds and NBO activity. Molecular dynamic studies and experimental data on the $\mathrm{SiO}_{2}-\mathrm{Al}_{2} \mathrm{O}_{3}-\mathrm{CaO}$ system have shown that low- $\mathrm{SiO}_{2}$, high-CaO glasses, which do not contain ${ }^{\mathrm{V}} \mathrm{Al}$, may have abundant NBOs and highly polymerized stable networks (Neuville et al. 2007), whereas glasses with over $40 \mathrm{~mol} \% \mathrm{SiO}_{2}$ and very low $\mathrm{Al}_{2} \mathrm{O}_{3}$ develop ${ }^{\mathrm{IV}} \mathrm{Al}$ in $\mathrm{Q} 4$ sites with the formation of ${ }^{\mathrm{V}} \mathrm{Al}$ and large NBO capacity (Kirkpatrick et al. 1986; Oestrike et al. 1987; Poe et al. 1994).

\section{ACKNOWLEDGMENTS}

The senior author is indebted to the Department of Mineralogy and Crystallography and the Electron Microscopy Laboratory of the University Complutense de Madrid, where part of this work was carried out, and to Fundación Banco de Santander. M. Gutierrez, R. Lozano, J. Maldonado, M. Reyes, Belém Sanlillo, and A. Maturano helped with the analytical work. This work was supported by the Consejo Nacional de Ciencia y Tecnología, CONACYT, Project D47075-F.

\section{REFERENCES CITED}

Albee, A.L. and Ray, L. (1970) Correction factors for electron probe microanalysis of silicates, oxides, carbonates, phosphates, and sulfates. Analytical Chemistry, 42, 1408-1414.

Allwardt, J.R., Poe, B.T., and Stebbins, J.F. (2005a) The effect of active temperature on $\mathrm{Al}$ coordination in high-pressure $(10 \mathrm{GPa})$ sodium aluminosilicate glasses. American Mineralogist, 90, 1453-1457.
Allwardt, J.R., Stebbins, J.F., Schmidt, B.C., Frost, D.J., Withers, A.C., and Hirschmann, M.M. (2005b) Aluminum coordination and densification of highpressure aluminosilicate glasses. American Mineralogist, 90, 1218-1222.

Allwardt, J.R., Stebbins, J.F., Terasaki, H.I., Du, L.S., Frost, D.J., Withers, A.C., Hirschmann, M.M., Suzuki, A., and Ohtani, E. (2007) Effect of structural transitions on properties of high-pressure silicate melts, ${ }^{27} \mathrm{Al} \mathrm{NMR}$, glass densities, and melt viscosities. American Mineralogist, 92, 1093-1104.

Angeli, F., Gaillard, M., Jollivet, P., and Charpentier, T. (2007) Contribution of ${ }^{43} \mathrm{Ca}$ MAS NMR for probing the structural configuration of calcium in glass. Chemical Physics Letters, 440, 324-328.

Armbruster, T. and Gunter, M.E. (2001) Crystal structure of natural zeolites. In D.L. Bish and D.W. Ming, Eds., Natural Zeolites, 45, p. 1-67. Reviews in Mineralogy, Mineralogical Society of America, Chantilly, Virginia.

Armbruster, T. and Kohler, T. (1992) Rehydration and dehydration of laumontite, A single crystal X-ray study at $100 \mathrm{~K}$. Neues Jahrbuch für MineralogiaAbhandlugen, 167, 385-397.

Baltisberger, J.M., Xu, Z., Stebbins, J.F., Wang, S.H., and Pines, A. (1996) Triplequantum two-dimensional ${ }^{27} \mathrm{Al}$ magic angle spinning nuclear magnetic resonance spectra of aluminosilicate and aluminate crystals and glasses. Journal of the American Chemical Society, 118, 7209-7214

Bence, A.E. and Albee, A.L. (1968) Empirical correction factors for the electron microanalysis of silicates and oxides. Journal of Geology, 76, 382-403.

Best, M.G. (1982) Igneous and Metamorphic Petrology, 630 p. Freeman, New York.

Bish, D.L. and Carey, J.W. (2001) Thermal behavior of natural zeolites. In D.L. Bish and D.W. Ming, Eds., Natural Zeolites, 45, p. 402-452. Reviews in Mineralogy, Mineralogical Society of America, Chantilly, Virginia.

Bishop, J., Madejová, J., Komadel, P., and Fröschl, H. (2002a) Influence of structural $\mathrm{Fe}, \mathrm{Al}$ and $\mathrm{Mg}$ on the infrared $\mathrm{OH}$ bands in spectra of dioctahedral smectites. Clay Minerals, 37, 607-616.

Bishop, J., Murad, E., and Dyar, M.D. (2002b) The influence of octahedral and tetrahedral cation substitution on the structure of smectites and serpentines as observed through infrared spectroscopy. Clays and Clay Minerals, 37, 617-628.

Castro-Govea, R., Siebe, C., and Abrams, M. (2001) Recent eruptive history of La Malinche volcano, Mexico: Towards the construction of a hazards map. American Geophysical Union, Fall Meeting, abstract V42C-1030.

Cormier, L., Ghaleb, D., Neuville, D.R., Delaye, J.M., and Calas, G. (2003) Chemical dependence of network topology of calcium aluminosilicate glasses, a computer simulation study. Journal of Non-Crystalline Solids, 332, 255-279.

Couty, R. and Velde, E.B. (1986) Pressure-induced and splitting in infrared spectra of sanidine and albite. American Mineralogist, 71, 99-104.

Cuadros, J. and Dudek, T. (2006) FTIR investigation of the evolution of the octahedral sheet of kaolinite-smectite with progressive kaolinization. Clays and Clay Minerals, 54, 1-11.

Davis, K.M. and Tomozawa, M. (1996) An infrared spectroscopic study of water related species in silica glasses. Journal of Non-Crystalline Solids, 201, 177-198.

Di Matteo, V., Carroll, M.R., Behrens, H., Vetere, F., and Brooker, R.A. (2004) Water solubility in trachytic melts. Chemical Geology, 213, 187-196.

Dingwell, D.B. and Webb, S.L. (1990) Relaxation in silicate melts. European Journa of Mineralogy, 2, 427-449.

Dirken, P.J., Jansen, J.B.H., and Schuling, R.D. (1992) Influence of octahedral polymerization of ${ }^{23} \mathrm{Na}$ and ${ }^{27} \mathrm{Al}$ in alkali fluoraluminates. American Mineralogist, 77, 718-724.

Farmer, V.C. (1974) Infrared Spectra of Minerals, 285 p. Mineralogical Society, London.

Fridriksson, T., Bish, D.L., and Bird, D.K. (2003a) Hydrogen-bonded water in laumontite. I, X-ray powder diffraction study of water site occupancy and structural changes in laumontite during room-temperature isothermal hydration dehydration. American Mineralogist, 88, 277-287.

Fridriksson, T., Carey, J.W., Bish, D.L., Neuhoff, P.S., and Bird, D.K. (2003b) Hydrogen-bonded water in laumontite II, Experimental determination of site-specific thermodynamic properties of hydration of the W1 and W5 sites. American Mineralogist, 88, 1060-1072.

Frondel, C. (1982) Structural hydroxyl in chalcedony (type B quartz). American Mineralogist, 67, 1248-1257.

Frost, B.R., Arculus, R.J., Barnes, C.G., Collins, W.J., Ellis, D.J., and Frost, C.D (2001) A geochemical classification of granitic rock suites. Journal of Petrology, 42, 2033-2048.

Fyfe, C.A., Gobbi, G.C., Klinawski, J., Thomas, J.M., and Ramdas, S. (1982) Resolving crystallographically distinct tetrahedral sites in silicalite and ZSM- 5 by solid-state NMR. Nature, 296, 530-533.

Galli, E., Passaglia, E., Pongiluppi, D., and Rinaldi, R. (1974) Mazzite, a new mineral, the natural counterpart of the synthetic zeolite $\Omega$. Contributions Mineralogy and Petrology, 45, 99-105.

Gómez-Tuena, A., Orozco-Esquivel, M.T., and Ferrari, L. (2005) Petrogénesis ignea de la Faja Volcánica Transmexicana. Boletin Sociedad Geologica Mexicana 57, 227-283.

Graetsch, H., Florke, O.W., and Miehe, G. (1985) The nature of water in chalcedony and opal-c from Brazilian agate geodes. Physical Chemistry of Minerals, 12 , 300-306. 
Hiradate, S. and Wada, S. (2005) Weathering process of volcanic glass to allophane determined by ${ }^{27} \mathrm{Al}$ and ${ }^{29} \mathrm{Si}$ solid-state NMR. Clays and Clay Minerals, 53, 401-408.

Hovis, G.L., Spearing, D.R., Stebbins, J.F., Roux, J., and Clare, A. (1992) X-ray powder diffraction and ${ }^{23} \mathrm{Na},{ }^{27} \mathrm{Al}$, and ${ }^{29} \mathrm{Si}$ MAS NMR investigation of nephelinekalsilite solutions. American Mineralogist, 77, 19-29.

Huebner, J.S. (1980) Pyroxene phase equilibria at low pressure. In C.T. Prewitt, Ed., Pyroxenes, 7, p. 213-288. Reviews in Mineralogy, Mineralogical Society of America, Chantilly, Virginia.

Ihinger, P.D., Hervig, R.L., and McMillan, P.F. (1994) Analytical methods for volatiles in glasses. In M.R. Carroll and J.R. Holloway, Eds., Volatiles in Magmas, 30, p. 66-121. Reviews in Mineralogy, Mineralogical Society of America, Chantilly, Virginia.

Iiishi, K., Tomisaka, T., Kato, T., and Umegakai, Y. (1971) Isomorphous substitutions and infrared and far infrared spectra of the feldspars. Neues Jahrbuch für Mineralogie Abhandlungen, 115, 118-119.

Irving, T.N. and Baragar, W.R.A. (1971) A guide to the chemical classification of the common volcanic rocks. Canadian Journal of Earth Science, 8, 523-546.

Johnson, J.R. and Hörz, F. (2003) Visible/near infrared spectra of experimentally shocked plagioclase feldspars. Journal of Geophysical Research, 108, 5120, DOI: 10.1029/2003JE002127.

Kelsey, K.E., Stebbins, J.F., Du, L.S., Mosenfelder, J.L., Asimow, P.D., and Geiger, C.A. (2008) Cation/disorder behavior and crystal chemistry of pyrope-grossular garnets, An ${ }^{17} \mathrm{O}$ 3QMAS and ${ }^{27} \mathrm{Al}$ MAS NMR spectroscopic study. American Mineralogist, 93, 134-143.

Keppler, H. and Bagdassarov, N.S. (1993) High-temperature FTIR spectra of $\mathrm{H}_{2} \mathrm{O}$ in rhyolite melt to $1300^{\circ} \mathrm{C}$. American Mineralogist, 78, 1324-1327.

Kinsey, R.A., Kirkpatrick, R.J., Hower, J., Smith, K.A., and Oldfield, E. (1985) High resolution ${ }^{27} \mathrm{Al}$ and ${ }^{29} \mathrm{Si}$ nuclear magnetic resonance spectroscopic study of layer silicates, including clay minerals. American Mineralogist, 70, 537-548.

Kirkpatrick, R.J. (1988) MAS NMR spectroscopy of minerals and glasses. In F.C. Hawthorne, Ed., Spectroscopic Methods in Mineralogy and Geology, 18, p. 341-403. Reviews in Mineralogy, Mineralogical Society of America, Chantilly, Virginia.

Kirkpatrick, R.J., Smith, K.A., Schramm, S., Turner, G., and Yang, W.H. (1985) Solid state nuclear magnetic resonance spectroscopy of minerals. Annual Review Earth and Planetary Science, 13, 29-47.

Kirkpatrick, R.J., Oestrike, R., and Weiss, C.A. (1986) High-resolution ${ }^{27} \mathrm{Al}$ and ${ }^{29} \mathrm{Si}$ NMR spectroscopy of glasses and crystals along the join $\mathrm{CaMgSi}_{2} \mathrm{O}_{6}-\mathrm{CaAl}_{2} \mathrm{SiO}_{6}$. American Mineralogist, 71, 705-711.

Le Bas, M.J., Le Maitre, R.W., Streckeisen, A., and Zanettin, B. (1986) A chemical classification of volcanic rocks based on the total alkali-silica diagram. Journal of Petrology, 27, 745-750.

Lee, S.K. (2004) Structure of silicate glasses and melts at high pressure, Quantum chemical calculations and solid state NMR. Journal of Physical Chemistry B, $108,5889-5900$

Le Maitre, R.W. (1976) The chemical variability of some common igneous rocks. Journal of Petrology, 17, 689-637.

Lindsley, D.H. (1980) Phase equilibria of pyroxenes at pressures $>1$ atmosphere. In C.T. Prewitt, Ed., Pyroxenes, 7, p. 289-307. Reviews in Mineralogy, Mineralogical Society of America, Chantilly, Virginia.

Lippman, E., Samoson, A., and Magi, M. (1986) High-resolution ${ }^{27}$ Al NMR of aluminosilicates. Journal American Chemical Society, 108, 1730-1735.

Massiot, D., Fayon, F., Montouillout, V., Pellerin, N., Hiet, J., Roiland, C., Florian, P., Coutures, J.P., Cormier, L., and Neuville, D.R. (2008) Structure and dynamics of oxide melts and glasses, A view from multinuclear and high temperature NMR. Journal of Non-Crystalline Solids, 354, 249-254.

McMillan, P.F. and Hofmeister, A.M. (1988) Infrared and Raman spectroscopy. In F.C. Hawthorne, Ed., Spectroscopic Methods in Mineralogy and Geology, 18, p. 99-159. Reviews in Mineralogy, Mineralogical Society of America, Chantilly, Virginia.

Morse, S.A. (1980) Basalts and Phase Diagrams, p. 49. Springer Verlag, New York.

Müller, D., Gessmer, W., Behrens, J., and Sheler, G. (1981a) Determination of the aluminum coordination in aluminum-oxygen compounds by solid-state highresolution ${ }^{27} \mathrm{Al}$ NMR. Chemical Physics Letters, 79, 59-62.

Müller, D., Hoebbel, D., and Gessner, W. (1981b) ${ }^{27} \mathrm{Al}$ NMR studies in aluminosilicate solutions. Influence of the second coordination sphere on the shielding of aluminum. Chemical Physics Letters, 84, 25-29.

Mungall, J.E. and Martin, R.F. (1994) Severe leaching of trachytic glass without devitrification, Terceira, Azores. Geochimica et Cosmochimica Acta, 58, 75-83.

Nash, D.B. and Salisbury, J.W. (1990) Infrared reflectance spectra of plagioclase feldspars. Abstracts Lunar Planetary Science Conference, 21, 845.

Neuville, D.R., Cormier, L., and Massiot, D. (2004) Al environment in tectosilicate and peraluminous glasses, $\mathrm{A}^{27} \mathrm{Al}$ MQ-MAS NMR, Raman, and XANES investigation. Geochimica et Cosmochimica Acta, 68, 5071-5079.

Neuville, D.R., Cormier, L., Montouillout, V., and Massiot, M. (2007) Local Al site distribution in aluminosilicate glasses by ${ }^{27} \mathrm{Al}$ MQMAS NMR. Journal of NonCrystalline Solids, 353, 180-184.
Newman, S., Stolper, E.M., and Epstein, S. (1986) Measurement of water in rhyolitic glasses, calibration of an infrared spectroscopic technique. American Mineralogist, $71,1527-1541$

Oestrike, R., Yang, W.H., Kirkpatrick, R.J., Hervig, R.L., Navrotsky, A., and Montez, B. (1987) High-resolution ${ }^{23} \mathrm{Na},{ }^{27} \mathrm{Al}$ and ${ }^{29} \mathrm{Si}$ NMR spectroscopy of framework aluminosilicate phases. Geochimica et Cosmochimica Acta, 51, 2199-2209.

Osborn, E.F. and Muan, A. (1960) Phase Equilibria Diagrams of Oxide Systems, 20 p. American Ceramic Society and the Edward Orton Jr. Ceramic Foundation, Columbus.

Passaglia, E. and Sheppard, R.A. (2001) The crystal chemistry of zeolites. In D.L. Bish and D.W. Ming, Eds., Natural Zeolites, 45, p. 69-116. Reviews in Mineralogy, Mineralogical Society of America, Chantilly, Virginia.

Petrini, R., Forte, C., Contin, G., Pinzino, C., and Orsi, G. (1999) Structure of volcanic glasses from the NMR-EPR perspective, a preliminary application to the Napolitan Yellow Tuff. Bulletin of Volcanology, 60, 425-431.

Phillips, B.L., Howell, D.A., Kirkpatrick, R.J., and Gasparik, T. (1992) Investigation of cation order in $\mathrm{MgSiO}_{3}$-rich garnet using ${ }^{29} \mathrm{Si}$ and ${ }^{27} \mathrm{Al}$ MAS NMR spectroscopy. American Mineralogist, 77, 704-712.

Poe, B.T., Macmillan, P.F., Coté, B., Massiot, D., and Coutures, J.P. (1993) $\mathrm{Mg}_{2} \mathrm{Al}_{2} \mathrm{O}_{4}$ and $\mathrm{CaAl}_{2} \mathrm{O}_{4}$ liquids in-situ high temperature ${ }^{27} \mathrm{Al}$ NMR spectroscopy. Science, $259,786-788$.

- (1994) Structure and dynamics in calcium aluminate liquids, high temperature ${ }^{27} \mathrm{Al}$ NMR and Raman spectroscopy. Journal of the American Ceramic Society, $77,1832-1838$

Raudsepp, M., Turnock, A.C., Hawthorne, F.C., Sherriff, B.L., and Hartman, J.S. (1987) Characterization of synthetic pargasitic amphiboles $\left(\mathrm{NaCa}_{2} \mathrm{Mg}_{4} \mathrm{M}^{3+} \mathrm{Si}_{6} \mathrm{Al}_{2} \mathrm{O}_{22}(\mathrm{OH}, \mathrm{F})_{2} ; \mathrm{M}^{3+}=\mathrm{Al}, \mathrm{Cr}, \mathrm{Ga}, \mathrm{Sc}, \mathrm{In}\right)$ by infrared spectroscopy, Rietveld structure refinement, and ${ }^{27} \mathrm{Al},{ }^{29} \mathrm{Si}$, and ${ }^{19} \mathrm{~F}$ MAS NMR spectroscopy. American Mineralogist, 72, 580-593.

Rehak, P., Kunath-Fandrei, G., Losso, P., Hildmann, L.B., Schneider, H., and Jaeger, C. (1998) Study of the Al coordination in mullites with varying $\mathrm{Al}, \mathrm{Si}$ ratio by ${ }^{27} \mathrm{Al}$ NMR spectroscopy and X-ray diffraction. American Mineralogist, 83 , 1266-1276.

Rossman, G.R. (1988) Vibrational spectroscopy of hydrous components. In F.C. Hawthorne, Ed., Spectroscopic Methods in Mineralogy and Geology, 18, p. 207-243. Reviews in Mineralogy, Mineralogical Society of America, Chantilly, Virginia.

Russell, J.D. and Fraser, A.R. (1994) Infrared methods. In M.J. Wilson, Ed., Clay Mineralogy, Spectroscopic and Chemical Determinative Methods, p. 11-67. Chapman and Hall, London.

Rutstein, M.S. and White, W.B. (1971) Vibrational spectra of high-calcium pyroxenes and pyroxenoids. American Mineralogist, 56, 877-887.

Salisbury, J.W., Walter, L.S., Vergo, N., and D'Aria, D.M. (1991) Infrared Spectra of Minerals, 266 p. John Hopkins University Press, Baltimore.

Servicio Geológico Mexicano (2007) Carta Geológica, escala 1,250000 E14-2, México.

Slejko, F.F., Petrini, R., Forte, C., Pedrazzi, G., Pinzino, C., and D'Antonio, M. (2003) The structure of dense and vesicular volcanic glass fragments from the Astroni tephra (Phlegracan fields, Italy) explored by spectroscopic techniques, implications on bubble expansion and dynamics of magma ascent. Journal of Non-Crystalline Solids, 323, 54-67.

Slejko, F.F., Petrini, R., and Forte, C. (2004) ${ }^{27} \mathrm{Al}$ MAS NMR spectroscopy on volcanic glasses from the Neapolitan Yellow Tuff (Southern Italy), Inference of A coordination and reactivity of aluminosilicate melts during phreatomagmatic explosions. Neues Jahrbuch für Mineralogie-Abhandlugen, 179, 311-324.

Stahl, K., Artioli, G., and Hanson, J.C. (1996) The dehydration process in the zeolite laumontite, a real-time synchrotron X-ray powder diffraction study. Physical Chemistry of Minerals, 23, 543-550.

Stebbins, J.F. (1995) Dynamics and structure of silicate and oxide melts, nuclear magnetic resonance studies. In J.F. Stebbins, P.F. Macmillan, and D.B. Dingwell, Eds. Structure, Dynamics and Properties of Silicate Melts, 32,p. 191-246. Reviews in Mineralogy, Mineralogical Society of America, Chantilly, Virginia.

Stebbins, J.F., Kroeker, S., Lee, S.K., and Kiczenski, T.J. (2000) Quantification of fiveand six-coordinated aluminum ions in aluminosilicate and fluoride-containing glasses by high-field, high-resolution ${ }^{27} \mathrm{Al}$ NMR. Journal of Non-Crystalline Solids, 275, 1-6.

Stolper, E.M. (1982) Water in silicate glasses, an infrared spectroscopy study. Contributions to Mineralogy and Petrology, 81, 1-17.

Stolper, E.M., Paque, J., and Rossman, G.R. (1982) The influence of oxygen fugacity and cooling rate on the crystallization of $\mathrm{CaAl}$ rich inclusions from Allende. Lunar Planetary Science, 14, 772-773.

Topliss, M.J., Dingwell, D.B., and Lenci, T. (1997a) Peraluminous viscosity maxima in $\mathrm{Na}_{2} \mathrm{O}-\mathrm{Al}_{2} \mathrm{O}_{3}-\mathrm{SiO}_{2}$ liquids, The role of triclusters in tectosilicate melts. Geochimica et Cosmochimica Acta, 61, 2605-2612.

Topliss, M.J., Dingwell, D.B., Hess, K.U., and Lenci, T. (1997b) Viscosity, fragility and configurational entropy of melts along the join $\mathrm{SiO}_{2}-\mathrm{NaAlSiO}_{4}$. American Mineralogist, 82, 970-990.

Topliss, M.J., Kohn, S.C., Smith, M.E., and Poplett, I.J.F. (2000) Fivefold coordinated aluminum in tectosilicate glasses observed in triple quantum MAS NMR. 
American Mineralogist, 85, 1556-1560.

van Reeuwijk, L.P. (1974) The Thermal Dehydration of Natural Zeolites. H Veenman and Zonen B.V., Wageningen, Netherlands.

Wang, L., Aardahl, C.L., Rappe, K.G., Trau, D.N., and Delgado, M.A. (2002a) Solidstate ${ }^{27} \mathrm{Al}$ nuclear magnetic resonance investigation in plasma-facilitated $\mathrm{NO}_{x}$ reduction catalysts. Journal of Materials Research, 17, 1843-1848.

Wang, L., Zhang, M., Redfern, S.A.T., and Zhang, Z. (2002b) Dehydroxylation and transformations of the 2:1 phyllosilicate pyrophyllite at elevated temperatures, an infrared spectroscopic study. Clays and Clay Minerals, 50, 272-283.

Witter, J.B., Kres, V.C., and Newhalt, C.G. (2005) Volcán Popocateptl, México. Petrology, magma mixing and immediate sources of volatiles for the 1994-present eruption. Journal of Petrology, 46, 2337-2366.
Zhang, Y. (1999) $\mathrm{H}_{2} \mathrm{O}$ in rhyolitic glasses and melts, Measurement, speciation, solubility and diffusion. Reviews in Geophysics, 37, 493-516.

Zhang, Y., Stolper, E.M., and Wasserburg, G.J. (1991) Diffusion of water in rhyolitic glasses. Geochimica et Cosmochimica Acta, 55, 441-456.

Zotov, N. (2003) Structure of natural volcanic glasses, diffraction vs. spectroscopic perspective. Journal of Non-Crystalline Solids, 32, 1-6. 